\title{
Article \\ Energy Transition as a Response to Energy Challenges in Post-Pandemic Reality
}

\author{
Darya Gribkova * and Yulia Milshina (D)
}

check for updates

Citation: Gribkova, D.; Milshina, Y. Energy Transition as a Response to Energy Challenges in Post-Pandemic Reality. Energies 2022, 15, 812. https://doi.org/10.3390/en15030812

Academic Editors: Edmundas Kazimieras Zavadskas and Behnam Zakeri

Received: 9 December 2021

Accepted: 20 January 2022

Published: 23 January 2022

Publisher's Note: MDPI stays neutral with regard to jurisdictional claims in published maps and institutional affiliations.

Copyright: (C) 2022 by the authors. Licensee MDPI, Basel, Switzerland. This article is an open access article distributed under the terms and conditions of the Creative Commons Attribution (CC BY) license (https:// creativecommons.org/licenses/by/ $4.0 /)$.

\author{
Institut Statisticheskikh Issledovaniy I Ekonomiki Znaniy Niu Vshe, HSE University, 101000 Moscow, Russia; \\ ymilshina@hse.ru \\ * Correspondence: dgribkova@hse.ru
}

\begin{abstract}
The concept of energy transition has been adopted by national governments, international and regional organizations. The COVID-19 pandemic triggered increasing attention to climate policy, energy transition, and economic resilience. This paper looks at energy transition in selected countries with the use of case studies-China, the European Union, India, Russia, Saudi Arabia, and the United States. The aim of the study is to analyze the main approaches to the energy transition in these countries and the barriers which may influence this process. The study applies foresight methods such as trend monitoring, case study, and STEPE methods for barrier analysis. The outcomes include identification of energy priorities in the national context, key directions for future transformation, and selected countries' approaches to the energy transition after the COVID-19 pandemic. All considered countries are taking measures for the energy transition, but the motives, pace, and priorities differ. Their approaches were grouped into ideological (the European Union, the United States) and pragmatic (Saudi Arabia, China, and India). Both groups attribute priority to the gradual shift to clean technologies and carbon-neutral energy generation. Russia occupies an intermediate position due to attention to consumers as well as high interest in diversification of budget revenues and the shift from fossil fuel. The list of barriers to energy transition includes an inappropriate level of technological development, inconsistency of renewable power generation, substantial/rapid increase in rare earth metals prices, economic sectors' dependence on fossil fuels, lack of investment in renewables, restricted access to technologies, trade barriers, lack of political will, use of access to advanced technology market as a political tool, and renewables' dependence on weather regimes, etc. The novelty of the study is in the scope of selected cases that give a broad overview of existing approaches to the energy transition, identification of two energy transition patterns, as well as trends, wild cards, and barriers on the way.
\end{abstract}

Keywords: energy transition; grand challenges; global trends; sustainable development; case study; pandemic; wild cards

\section{Introduction}

Population growth, economic development, and rising energy consumption increase the need for reliable and safe energy systems that are resilient to external and internal challenges. The Sustainable Development Goal 7 on energy sets the goal of achieving access to affordable, reliable, sustainable, and modern energy for all [1]. Currently, the concept of the energy transition is widely accepted by national governments and international and regional organizations. The term "energy transition" firstly appeared after the 1973 oil crisis. Then it received its global popularity after the 1979 oil crisis and the United Nations Conference on new and renewable sources of energy in Nairobi in 1981 [2].

Previously, the transition from one energy source to another lasted for a century or more and its main reasons were resource scarcity, high labor costs, and technological innovations [3]. Energy transition involves changes in energy generation as well as large-scale transformations in modes of production, business sectors, and labor markets, and targeted 
technological, political, economic, institutional, and sociocultural changes. A. Grubler (2012) points out that the "need" for the next energy transition takes place as current energy systems are unsustainable according to all environmental, social, and economic criteria [4]. Based on the synthesis of the case studies, he defines the characteristics of successful energy transition policies: persistence/continuity, alignment, and balance. These characteristics reflect the transition process as time-consuming and multidimensional in scope.

One of the key questions raised in current research is "do national economies move away from established energy sources, i.e., fossil fuels and nuclear power?". York and Bell (2019) suggest the phrase "energy addition", describing the expansion of new energy source production [5]. To sharpen analytic acuity, they argue that the term "energy transition" should be used only when there is an actual retreat from one source to another. This proposition relates to the issue of the different rates at which countries include new energy sources into their energy balances and increase shares of these resources. EU members' policies, which have good outcomes in the implementation of clean-tech, show that they do not refuse older energy resources for good and all. The current energy crisis, manifested in the spike in natural gas prices, is a reason to believe that the circumstances can push the European Union to reconsider the attitude towards nuclear energy and it will likely reach the status of a green source of energy. So if we use the term "energy transition" we should take into account that it does not mean complete and irreversible refusal of older energy resources.

Changes brought by the pandemic already influence the dynamic of the energy transition. On the one hand, it stalled the progress in technology implementation as it exacerbated economic issues, especially in middle- and low-income countries, and negatively affected production and supply chains. On the other hand, the pandemic has become a driver for many trends, including the energy transition, and sustainability transitions were included on the agendas of many local and national governing bodies. C. Kuzemko and M. Bradshaw et al. (2020) emphasize that the economic and social impacts of COVID-19 will influence the policies of sustainable energy transition over the next few years [6]. Due to economic and social issues, energy transition and politics are intertwined $[7,8]$. The work of Kuzemko et al. identifies initial implications of the pandemic for the global energy system and considers the politics of sustainable energy transition. It focuses on four key themes that form the politics of the energy transition: the short, medium, and long-term temporary factors of energy system change; (ii) practices of clean-tech investment and divestment from traditional fuels; (iii) structures and scales of energy governance; and (iv) social mobility, work, and public health. Our paper focuses on the politics of six selected cases and analyzes its strategy documents to point out top development priorities (socioeconomic and technologic). Above all, it encompasses the existing plans and strategies accepted before the pandemic. For this goal, the case study approach has been applied.

The current energy transition involves the reduction in hydrocarbons and movement to renewables, the use of advanced technologies, and environmental pollution reduction. However, there is no single pace and universal pattern for energy system transformation that fit all countries. The energy transition has to take into account a set of parameters. A level of economic development, energy supply and demand, national security interest, and a country's position in energy trading define specific policy measures across countries and readiness for the effective energy transition. Pastukhova and Westphal (2020) designate energy transition as "a policy-driven process that involves systematic shifts towards (a) sustainable and climate-friendly, economically efficient and secure energy system(s)" [9]. Each country needs to determine its own best energy policy pathway considering its national economic development and priorities [10].

This paper seeks to answer the following research questions:

- What are the main approaches to the energy transition and what factors do they depend on?

- What current and future barriers (including unpredictable, but influential events-wild cards) may influence the process of energy transition? 
In the first chapter, there is a literature review of papers and documents related to the energy transition. Selected papers are reports of the international organizations and some of the most cited publications in the Web of Science for the last five years. The second chapter is devoted to the analysis of how the global energy landscape and the most influential trends are changing due to the COVID-19 pandemic influence. The next chapter describes methodological approaches and the reasons for selecting the chosen case studies applied in this paper. The fourth chapter includes case studies of selected countries. The final part of the paper includes a brief description of the approaches (pragmatic and idealistic) of selected cases towards energy transition, existing and potential barriers, and possible directions of future research

\section{Literature Review}

Analysis of the literature has shown that the energy transition is a phenomenon that is quite often described in scientific literature and thematic international reports, especially in the last decade, when the climate agenda and energy security issues have acquired particular importance. The 2015 UN Sustainable Development Goals impacted the analytical framework for energy transition. One of the most disputable questions is related to substance and sense of the energy transition-what processes does it imply? Most often, the authors analyze energy transition policies at the national or local levels, examine a particular case, and review its positive and negative effects.

\subsection{Definitions and Key Features}

The global and national energy systems face grand challenges that in general can be classified as economic, social, climate, technological, and political based on the main areas of human activity (Table 1). Human activities significantly impact the functioning of Earth systems-population growth, economic development, and increasing energy consumption reinforce the need for reliable and safe energy supply, which is resilient to external and internal challenges and can adapt to future unexpected shocks. It is very important to highlight that energy transition should be considered not as a global challenge, but as a tool to cope with grand challenges.

Table 1. Grand challenges for energy systems.

\begin{tabular}{|c|c|}
\hline Type & Grand Challenges \\
\hline Social & $\begin{array}{ll}\text { - } & \text { Population growth } \\
\text { - } & \text { Responsible consumption model spreading } \\
\text { - } & \text { Increasing inequalities in access to energy resources }\end{array}$ \\
\hline Technological & $\begin{array}{ll}- & \text { Obsolete infrastructure } \\
\text { - } & \text { Cyberattacks and infrastructure disruptions } \\
\text { - } & \text { Hazardous waste, including nuclear, disposal issues } \\
\text { - } & \text { Gap in technological development within countries }\end{array}$ \\
\hline Economic & $\begin{array}{ll}\text { - } & \text { Increased consumption of heat and electricity due to urbanization } \\
\text { - } & \text { Shifting consumer demand for energy resources to Asia and Latin America } \\
\text { - } & \text { Changes in the global energy balance, increased share of renewables } \\
\text { - } & \text { Increasing extracting cost } \\
\text { - } & \text { Trade and investment protectionism } \\
\text { - } & \text { Price shocks }\end{array}$ \\
\hline Ecological & $\begin{array}{l}\text { - Negative effects on the environment and human health in the process of extraction and combustion of hydrocarbons } \\
\text { - } \quad \text { Degradation of natural ecosystems } \\
\text { Resource depletion }\end{array}$ \\
\hline Political & $\begin{array}{ll}- & \text { Stricter environmental requirements } \\
- & \text { Geopolitical instability } \\
- & \text { Economic confrontation between great powers } \\
\text { - } & \text { International cooperation mechanisms' inefficiency }\end{array}$ \\
\hline
\end{tabular}

Resource: compiled by the authors based on WEF, 2020 [11]; PwC, 2020 [12].

For example, the World Economic Forum (WEF) defines an effective energy transition as a timely transition towards a more inclusive, sustainable, affordable, and secure energy system that provides solutions to global energy-related challenges, while creating value for business and society, without compromising the balance of the energy triangle [13]. In 
IRENA's report ("Global energy transformation-roadmap to 2050") energy transformation is defined as a means of achieving energy transition [14]. The World Energy Council (WEC) defines energy transition as fundamental structural changes in the energy sector that occur worldwide and are not an isolated phenomenon [15].

Markard (2018) defines energy transition as a new qualitatively different phase of earlier transition dynamics, as an example of a broader set of sustainability transitions [16]. Sustainability transitions research emphasize the interconnectedness of social, technical, institutional, and political changes, and stress path-dependency and lock-in [17]. The main issues in sustainability transitions are emergence and decline-sustainable technologies, policies, practices, and ways of organizing are supposed to emerge, while unsustainable alternatives decline [18]. The energy transition cannot be considered separate from the socioeconomic system [14], it is a combination of purposeful technological, political, economic, institutional, and sociocultural changes [19].

Henderson and Mitrova (2020) argue that the current energy transition can be viewed as the fourth in a series of fundamental structural transformations of the global energy sector [20]. The first transformation-from biomass to coal—is defined as a period between 1840 and 1890, when the share of coal in the energy balance increased from 5\% to 50\% [21]. The second stage is related to the fast penetration of oil during the period from 1915 to 1975, and the third transition involved the partial replacement of both coal and oil by natural gas in 1930-2017 [20]. If the main driver of the first three transitions was economic efficiency, then now it is combating global climate change. Compared with the previous changes, the current energy transition is being driven by government policy and regulations [22]. As a motive of the transition is to mitigate climate change, the feature of the fourth transition is the rise of the share of renewables.

According to the International Renewable Energy Agency (IRENA), renewable energy must account for around two-thirds of the world's total energy supply by 2050 [14]. The 2021 International Energy Agency's (IEA) Net Zero also describes a scenario of two-thirds of the total energy supply in 2050 being from wind, solar, bioenergy, geothermal, and hydro energy [23]. In both cases, there are certain guidelines for improving economies' energy efficiency, a set of steps the governments should take to achieve a renewables-based energy system. However, will the states be guided by considerations of national energy security or preferences of international organizations? Obviously, presented estimates are a possible scenario, but not a forecast, since the reality will depend on the specific policy. The energy transition refers to different outcomes in every region-Europe, the United States, Asia, and the Middle East [22], and moreover countries. As trends and innovations gain momentum their impact increases and the variety of possible future outcomes becomes greater, especially since critical uncertainty increases. In these circumstances, governments face the need to choose (or to balance) between environmental sustainability, energy security, and energy equity.

It is very important to take into account the climate conditions to install renewable energy systems across Köppen-Geiger climates [24]. Today, there is an increasing interest in implementing this classification to identify changes in climate and potential changes in vegetation over time [25]. Mazzeo et al. (2020) highlighted that one of the most suitable climate conditions to install a GC HRES (grid-connected hybrid renewable energy system) is in New Delhi (India) from an energy point of view, with $48 \%$ of energy exchanged with the grid per each $\mathrm{kWh}$ required by the load [25].

Blazquez, Fuentes, and Manzano (2020) argue that the energy transition is driven by policies rather than by technology improvements [26]; state policy plays a profound role in the energy sector transformation because of its importance for the country's economic development and national security. This determines the need for analysis of national energy strategies. It provides an overview and general guidelines for policymakers, the business sector, investors, and researchers, as it represents a concept of the main directions of changes in economic, technological, and other related dimensions. Only government has the authority and a variety of tools to stimulate the energy transition-the deployment of 
specific technologies, investment in specific sectors, encouragement of research, subsidies, and taxation, and maintenance in the case of crises. Countries' energy transition readiness improved, mainly due to an increased level of political commitment, and better access to capital and investment [13]. WEF sets six dimensions enabling transition readiness, and two of them are directly related to national strategies: regulations and political commitments, and institutions and government.

Efficient governance is key for energy transformation. Political will is the main difference between the current and past energy transition; the outcome will depend on the relative intensity of policy stimulus [26]. IRENA identifies six areas where policy and decision-makers need to act [14]:

1. Tap into the strong synergies between energy efficiency and renewable energy;

2. Plan a power sector for which renewables provide a high share of the energy;

3. Increase use of electricity in transport, building, and industry;

4. Foster the system-wide innovation;

5. Align socioeconomic structures and investment with the transition;

6. Ensure that transition costs and benefits are fairly distributed.

This research defines the energy transition as a qualitative shift from an economic system dependent on specific energy resources and technologies to a different one. The scale of the energy transition is determined not simply by the transformation of the energy system, but the economy as a whole. It involves large-scale changes in the business sector, production patterns, and labor markets [27]. Reliable permanent access to energy resources is one of the national priorities, which is why energy transition takes a significant place in national strategies, affecting different dimensions, including economic and national security. Technologies play a crucial role in the energy transition; renewable energy technologies are an important group of technologies for sustainability transitions [28]. However, energy transition is rather a policy-driven process. This paper reviews the national priorities and key goals in the energy sector and identifies the role of the energy transition and the kind of technologies national policies prioritize.

\subsection{Global Energy Landscape and Trends}

Global markets are constantly transforming inter-fuel competition and climate policy impacts on the development of the growing global energy system; new promising energy resources appear and disruptive technologies are spreading. COVID-19, which swept the world in 2020, has become a driver of these trends.

The pandemic has become a driver for many trends, including the energy transition [29]. It revealed obvious weaknesses in the energy system and related economic and social spheres [30,31]. Exponential global economic growth, requiring constant resource reinforcement, cannot continue indefinitely. The aging of the population, technological development, and a decline in the planet's ability to cope with the consequences of human economic activity are supporting the trend towards sustainable development. The explicit interconnection of energy problems with the sources of economic growth, and the wellbeing of the population and the environment, has made the energy transition a part of the global agenda and relations between states. The energy transition can be considered as an answer to challenges accelerated during the pandemic.

Pandemic-driven crises coincided with a structural decline in the fossil fuel market, driven by commitments towards decarbonization by a number of countries, and wider technological changes [32]. Both inter-fuel competition between coal and natural gas, and between carbon carriers and renewables, reflects in the global and national energy balances. All fossil fuel sectors face competition, both within traditional markets and from other energy sources [33], due to growing pressure from environmental regulations and social movements, the rapid development of energy efficiency technologies, the reasons of affordability and economic effectiveness, and energy price volatility. One more trigger of this competition is contesting between OPEC + countries and producers of unconventional oil (mainly the United States and Canada, which are unbound by political agreements). 
Because of the growing competition for consumer markets, there is an apparent tendency for spot pricing to gradually dominate over long-term bindings to oil prices [33].

The COVID-19 pandemic affected short-term demand significantly and could continue to do so in the long term because of negative economic consequences and the dilemma between the future benefits of sustainable development and today's challenges of providing the population with energy. The ongoing world economic growth remains to be challenged by uncertainties related to the spread of COVID-19 variants. The COVID-19 impact will be felt for years to come, firstly, it directly affected energy complexes, engaged workers, and enterprises' ability to achieve sustainability. Then, restrictive measures led to disruptions in supply chains, a sharp decline in economic activity, and a reduction in demand. The decline in demand provoked tough price competition and severe price drop. Possible future wild cards such as this pandemic make forecasting more difficult and less certain. For instance, in 2020 Russian experts suggested that the oil price was to stay at $\$ 40-60$ per barrel in 2021, but recognized the possibility of the fall to $\$ 20$ per barrel in case of a negative scenario [34] However, in the second half of 2021 oil prices started rising because OPEC+ countries decided to raise oil output by 400,000 barrels per day in November 2021 [35]. In October, crude oil prices rose above $\$ 80$ per barrel [36]. The Bank of Russia has raised the forecast oil price for 2021 and 2022 to $\$ 70$ and $\$ 65$ per barrel, respectively [37]. The Bank of America expects the Brent crude benchmark to hit $\$ 120$ per barrel by the end of June 2022 [38].

According to the IEA's outlook before the COVID-19 crisis, energy demand will grow by $12 \%$ in 2019-2030. The growth in demand will be driven mainly by demand in Asian countries. In 2020, energy demand growth was estimated at $9 \%$ if the pandemic was brought under control and the global economy began to return to pre-crisis level in 2021, and $4 \%$ if the global economy returns to pre-crisis level in 2023 [39]. Demand for coal in Europe and North America will decline by 2025 after an increase in 2021; on the contrary, in Asian countries, the demand will rise, for instance, in China and India by $2 \%$ and $17 \%$, respectively [40]. According to the November oil market OPEC report, in 2022 the growth in global oil demand is estimated to reach $100.6 \mathrm{mb} / \mathrm{d}(96.4 \mathrm{mb} / \mathrm{d})$ [41]. In the first half of 2021, industry and economic life, in general, started gradually recovering from the recession. This led to the increasing need for energy resources-gas in Europe [42] amid falling alternative electricity generation and on the eve of the heating season, and coal in China, whose industry still heavily relies on coal. Shortages of coal and natural gas in China and Europe have boosted prices for the fuel burned for electricity generation.

The pandemic impact on the global energy market is undoubtedly huge, but the possibility of accurate foresight is reduced. For instance, COVID-19 could become both a driver and a barrier to the wide implementation of renewables. First, it may be due to a reduction in the global energy demand; the decline in demand could become longterm if the practice of remote working becomes a permanent phenomenon and the global demand for office spaces declines [43]. The slowdown in the process of international climate negotiations could also be regarded as a signal of resettlement of national priorities. At the same time, renewables can become a priority of anti-crisis strategies, but in countries capable of providing appropriate technologies. Thus, in OECD, oil demand is unlikely to return to pre-crisis 2019 level, and after a slight growth, it may decline by the end of the medium term [44]. In this context, it is necessary to take into account the background of the forecast's sources, its involvement, and stake.

This uncertainty makes countries put "market risks" in front of their policy and planning - economic stimulus and employment are and will be a top government's priority; international energy companies will rely more on approaches that enhance the resilience of investments, including climate-related risks [32]. Uncertainty of the future and a variety of factors determine different scenarios. Some of them are presented below in Tables 2 and 3. Table 2 describes possible scenarios with more specific features and numerical indicators of the global energy sector. Table 3 takes possible variants with COVID-19 as starting points and describes peculiarities of different dimensions such as markets, consumer demand, 
state of the industry, international cooperation, etc., which in many ways affect the global energy sphere.

Table 2. Possible energy futures by IEA, 2020.

\begin{tabular}{|c|c|c|c|}
\hline Stated Policy Scenario & Delayed Recovery Scenario & Sustainable Development Scenario & Net Zero Emissions by 2050 Case \\
\hline $\begin{array}{l}\text { - } \quad \text { COVID-19 is brought under control } \\
\text { in } 2021 \\
\text { - } \\
\text { Global economy returns to pre-crisis } \\
\text { levels in } 2021 \\
\text { Average annual GDP growth is } 3 \% \\
\text { in } 2019-2030 \\
\text { Renewables meet } 80 \% \text { of the growth } \\
\text { in global electricity demand to } 2030 \\
\text { - } \quad \text { Coal share in the } 2040 \text { energy mix } \\
\text { falls below } 20 \% \\
\text { Oil demand flattens out in the 2030s } \\
\text { - } 30 \% \text { rise in global natural gas } \\
\text { demand by } 2040 \text { is concentrated in } \\
\text { South and East Asia }\end{array}$ & $\begin{array}{l}\text { - } \quad \text { COVID-19 ushers } \\
\text { in a decade } \\
\text { Global economy returns to } \\
\text { its pre-crisis size in } 2023 \\
\text { Average annual GDP } \\
\text { growth is 2,2\% in } \\
\text { 2019-2030 } \\
\text { Global energy demand } \\
\text { rebounds to its pre-crisis } \\
\text { level in } 2025 \\
\text { Global coal demand } \\
\text { reaches about } 4200 \text { mtce } \\
\text { in 2040 } \\
\text { Global oil demand flattens } \\
\text { out in the 2030s }\end{array}$ & $\begin{array}{l}\text { Achievements in sustainable } \\
\text { energy objectives in full } \\
\text { - } \quad \text { Strong advance of renewable } \\
\text { sources of generation } \\
\text { Global coal demand falls to } \\
1900 \text { mtce in } 2040 \\
\text { - } \quad \text { Global oil demand falls below } \\
70 \mathrm{mb} \backslash \mathrm{d} \text { after } 2038 \\
\text { - } \\
\text { Additional investment of } \$ 1 \\
\text { trillion a year in } 2021-2023 \text { is } \\
\text { directed towards improvements in } \\
\text { efficiency, low-emissions power } \\
\text { and electricity grids, and more } \\
\text { sustainable fuels } \\
\text { Improvements in cities' air quality } \\
\text { by } 2030 \text { without the disruptions to } \\
\text { economic activity }\end{array}$ & $\begin{array}{l}\text { - A rising number of countries } \\
\text { and companies are targeting } \\
\text { net-zero emissions by } \\
\text { midcentury } \\
\text { Strong advance of renewable } \\
\text { sources of generation } \\
\text { Low-emissions sources } \\
\text { provide nearly } 75 \% \text { of global } \\
\text { electricity generation in } 2030 \\
\text { More than } 50 \% \text { of passenger } \\
\text { cars sold worldwide in } 2030 \\
\text { are electric (from } 2.5 \% \\
\text { in 2019) }\end{array}$ \\
\hline
\end{tabular}

Resource: IEA, 2020 [39].

Table 3. Four plausible scenarios of the future of the global energy sector by WEC, 2020.

\begin{tabular}{|c|c|c|}
\hline Scenario & Features & Signals \\
\hline Restore & $\begin{array}{ll}- & \text { Mild COVID-19 } \\
- & \text { Manageable response } \\
& \text { Quick recovery }\end{array}$ & $\begin{array}{l}\text { China's factories back at } 80 \% \text { capacity as measures are lifted } \\
\text { Mitigation measures start to have discernible impact to reduce death/infection rates } \\
\text { Scientists announce credible vaccination testing } \\
\text { Swift recovery and rebounding consumer confidence allow companies to return to normal business }\end{array}$ \\
\hline Renewal & $\begin{array}{ll}-\quad & \text { Mild COVID-19 } \\
\text { Manageable response } \\
\text { New era of global } \\
\text { cooperation }\end{array}$ & $\begin{array}{l}\text { Business leaders are declaring that maximizing profit is not acceptable anymore } \\
\text { Ramp up of virus testing capacity in many countries (introduction of home testing) } \\
\text { New case rates in Italy, Spain, and other European countries do not increase after restrictions measures } \\
\text { are relaxed } \\
\text { New global fund is developed to inject stimulus to protect vulnerable communities and SMEs } \\
\text { Countries coordinate tactics for more effective response }\end{array}$ \\
\hline Rewind & $\begin{array}{ll}- & \text { Tough COVID-19 } \\
- & \text { Difficult response } \\
& \text { Strong national states }\end{array}$ & $\begin{array}{l}\text { Big manufacturers are moving their production facilities to domestic markets } \\
\text { The virus is spreading to new parts of the world (Africa, India, etc.) } \\
\text { Distrust and competition between countries for medical supplies with increased tension } \\
\text { Increased cases of violence in local communities as people cannot effectively cope with lockdown measures }\end{array}$ \\
\hline Regenerate & $\begin{array}{ll}- & \text { Tough COVID-19 } \\
-\quad & \text { Difficult response } \\
\text { Emergence of new } \\
\text { regional order }\end{array}$ & $\begin{array}{l}\text { Business leaders start looking at the regenerative models } \\
\text { Birth of new regional political alliances with coordination for effective response and to find vaccines } \\
\text { Compliance with public health } \\
\text { Recommendations are more difficult to enforce in many countries } \\
\text { Rebound of epidemic in China } \\
\text { Development of further regionalism }\end{array}$ \\
\hline
\end{tabular}

Resource: WEC, 2020 [45].

The energy transition is considered as an answer to challenges modern nations face, but not only in the energy sector. Because of interconnections among the energy sector and other spheres of human activity, changes influence economic and social spheres, and this circumstance determines the choice of individual strategies by states. These strategies can be reviewed due to shifts in national economic or technological development, geoeconomic and geopolitical transformations, or unpredicted events. Therefore, the analysis of national energy strategies and other related action plans can provide a more realistic picture of the future of the global energy sector.

The review of similar research showed that more common are articles focusing on one to two cases, examining the energy transition in a particular country, the base conditions and peculiarities, and the priorities of national policy [46-48]. However, there are papers which include analysis of a wide scope of cases. For instance, Fragkos et al. (2021) explore national low-emission scenarios of 11 selected countries. It takes into account the current climate pledges and national circumstances of every case [49]. It estimates the possible levels of emission reduction scenarios up to 2050 and provides a deep analysis of the key decarbonization options, economic implications, and the consistency of the national lowemission pathways with the Paris Agreement's goals. Authors highlight the importance of climate agenda and adaptation of low-carbon technologies as well as long-term policy 
and regulatory frameworks. According to the paper, a key role in narrowing the gap of current policies with the Paris goals is to play national low-emission development strategies considering countries' policy priorities. As this paper focuses on detailed representations of the energy, transport, and land systems, and provides insights on energy systems and economic effects, we propose to focus on the political dimension. Unlike the studies that take a macro-level approach, the paper of Liao et al. (2021) is focused on the local level of the energy choices by households in lower and middle-income countries [50]. The set of studies included 26 countries (10 Asia-Pacific countries, 12 African countries, and 4 Latin American countries). Based on differences in transition types, the paper highlights the regional trends. Quantitative studies in this paper measure outcomes of the adaptation of clean energy related to different aspects in education, health, environment, and income.

Lack of certainty, the rising influence of geopolitics, and disruptive technologies are key characteristics of the modern energy system. The growing demand for energy resources in developing countries, non-obviousness of long-term positive consequences of the energy transition for the population, specific economic conditions, and availability of technological bases for energy transition make forecasting difficult.

\section{Methodology}

This paper methodology is based on foresight methods such as trend monitoring, case study, and barriers analysis. As mentioned above, the energy transition is a specific process for every country and will be defined by national strategies. The global energy landscape is heavily dependent on several key stakeholders in the production and consumption of energy resources. In-depth case study analysis can help to examine existing approaches to the energy transition implementation for a specific country, in order to determine declared energy goals and how they correlate with strategies in related spheres. Existing and possible barriers can also be approached through this tool [48,51-53].

\subsection{Case Study Approach}

The case study method is the most widely used in qualitative research [54]; it enables progress with research on the emerging phenomena (energy transition) and patterns (national models of the energy transition). According to Simons (2009), the "case study is an in-depth exploration from multiple perspectives of the complexity and uniqueness of a particular project, policy, institution, program or system in a 'real life' context" [55]. In this paper, the case study method is notably suited for exploring complex phenomena such as energy transformation. The observational nature of the case study approach helps to form a detailed picture and identify common patterns among particular cases [56]. Comparison of case studies can be used to better understand the category of phenomena [57].

Our primary objective was to examine several different cases of transition. The sample was restricted by the most effluent actors forming the global energy landscape, nevertheless, our findings cannot be automatically generalized to other, especially less developed, countries. We determined what the energy transition means and what challenges the energy transition can respond to in every selected case, taking into account national energy contexts. We figured general provisions for future development in national energy strategies with the focus on the main directions of technical development in different macroeconomic and institutional characteristics.

As selected cases differ in their development priorities, economic, technological, and institutional (management) characteristics, results can be used to understand the possible ways for the energy transition. We found it reasonable to consider the EU as one actor, given its energy union and general external policy in the energy sphere, but future research can be more detailed and examine every member state's policy based on unique economic, technological, and political incentives to the energy transition. Therefore, the selected cases were analyzed by the following key dimensions: role of energy complex in the national economy; position on fossil fuels; and energy transition priorities. 


\subsection{Trend and Barriers Analysis}

Complex systems for global trends monitoring integrate quantitative and qualitative methods, which range from advanced data mining to other traditional foresight methods, in particular horizon scanning, scenarios building, expert panels, and wild cards analysis $[58,59]$. The quantitative methods are based on the big data mining system iFORA ('intelligent foresight analytics' (iFORA) system developed at the Institute for Statistical Studies and Economics of Knowledge, National Research University Higher School of Economics; the iFORA system applies an integrated database of diverse information and data sources with more than 450 million documents), created in the Higher School of Economics (HSE) [60]. It involves the in-depth natural language processing utilizing text-mining, machine learning, and science bibliometric and technology analysis. On the first stage, specialized sources of information from the iFORA database (more than 450 million documents: scientific papers, patents, and reports of international and national organizations, etc.) and other external data bases are selected. The next stage includes big data processing, searching for implicit relationships, and identifying patterns. At the following stage, analytical materials (including semantic and trend maps) are formed. The process is completed by expert validation and recommendation generation. Experts also identify barriers and drivers of trend development, as well as effects of trend realization on economic, social, political, ecological, and technological spheres.

The potential of energy transition can be restrained due to several barriers. To identify these factors, the STEPE methodology (social, technological, economic, political, and environmental) has been applied. Such a classification of barriers makes it possible to determine the areas that are affected by the energy transition, to assess its impact on them. The original form of ETPS (economic, technological, political, and social) was presented in the 1967 publication "Scanning the business environment" by F. Aguilar [61], which was then transformed into STEP for strategic assessment of various trends. For macroanalysis of the external environment or scanning of environmental changes, it has been converted to STEPE (E-ecological). The STEPE structure includes the following categories: social, technological, economic, political, and environmental.

We reviewed energy strategies and plans regarding the energy transition and studied planned and existing energy projects to determine what types of goals and objectives are being set; what financial and institutional implementation mechanisms will be used? A review is useful to identify existing resource and technological bases, costs of the technologies, financial tools (public, private, and international), the status of heating and electricity systems, socioeconomic effects, and environmental impacts.

\section{Case Studies Analysis}

The following sections describe selected cases and brief characteristics for each of them. Key features of these cases should give an idea of why these countries have a significant impact on the global energy system and why it is essential to examine their energy transitions. Selected cases include Russia, the United States, China, India, Saudi Arabia, and the European Union.

\subsection{Case Selection}

Among different levels of policy (national, sub-, and supranational) the national level remains most important for the development of energy policy as national priorities determine the government's actions first. Official documents offer investors a window into how the government understands challenges and opportunities in the energy sector and can guide them with their future planning. National strategies and plans are the best available indicators of policymakers' energy intentions and can be a guide to the future transformation of the energy sector, and therefore merit careful consideration. Most cases on energy transition in the literature mainly focus on cases of northern countries and less on specific cases of southern countries, predominantly China and India. O. Akizu et al. (2017) define two tracks-the energy transition in the Global North and the Global South, 
taking into account sociocultural, economic, political, and technological trigger factors of both global realities [62]. They have taken an effort to involve political, environmental, and engineering research to offer a multidisciplinary approach. The countries analyzed in this paper are Russia, China, India, the United States, Saudi Arabia, and one intergovernmental organization-the EU, as its general rules impose certain requirements on all members in the energy sphere. All selected countries are key players in the global energy sphere and represent both the Global North and the Global South. Their shares in global energy, changes in their supply and demand, as well as agreements among them, impact the global energy market.

Russia takes a unique place within the framework of the global energy system being at the same time a large producer, exporter, and consumer of all types of carbon energy resources, and one of the world leaders in nuclear energy and hydropower. Russia is the second-largest producer $(12.6 \%$ of world total) and a net exporter of crude oil, the second-largest producer $(18.3 \%$ of world total) and the largest net exporter of natural gas, and the sixth-largest producer (5.3\% of world total) and the third-largest net exporter of coal [63]. Currently, the global energy system is in the process of transformation which affects Russia's energy sector too. Russia's Energy Strategy defines the turn of the 20302040 s of the 21st century as a time horizon of profound transformation [64]. The energy complex plays the role of the basic infrastructure and basis of the budget system (30-40\% of federal budget revenues [65], which makes the energy transition an inevitable policy to energy grand challenges.

The United States is the world's largest producer $(16.7 \%$ of world total) and the second largest net importer of crude oil, the world's largest producer $(23.4 \%)$ and the fifth-largest net exporter of natural gas, and the third-largest producer of coal (8.1\%) [63]. The U.S. energy policy is closely related to the national security policy and is used as a foreign policy instrument. For instance, the first paragraph of the European Energy Security and Diversification Act of 2019 stipulates assistance for European countries to reduce their dependence on energy resources from Russia [66]. America's experts and political establishment consider global powers, such as Russia and China, as posing strong competition for the U.S. energy strategy.

China is the sixth-largest producer ( $4.3 \%$ of world total) and the largest importer of crude oil; the fourth producer (4.4\% of world total) and the largest net importer of natural gas; and the largest producer $(46.6 \%)$ and a net importer of coal. China accounts for $10.9 \%$ of the global nuclear production [63]; China's policy is to have a closed nuclear fuel cycle and it considers the promotion of its advanced nuclear power equipment as a way to go global in the sphere of nuclear energy [67]. Globally, the energy transition will be significantly influenced by China's technology policy. For example, China's share of global lithium-ion battery manufacturing in 2020 was 77\% [68], and it is a global leader in the manufacturing of equipment for solar and wind power generation [69]. In recent decades, China has undergone an immense economic transformation that required a huge amount of energy resources, which has moved it to the center of the global economy [70]. China had the largest growth in energy demand each year for the last 15 years [71] (Figure 1). As the 2021 energy crisis showed, the Chinese economy still needs more resources for further development and is still heavily reliant on fossil fuels, including coal.

India has made huge strides in the energy sector in recent years [72] and takes an important place in the global energy sphere. India is largely import-dependent; it is the third-largest net importer of crude oil, and the second-largest producer $(9.7 \%$ of world total) and the second largest net importer of coal [63]. Its geographic location creates both advantages and vulnerabilities: India is adjacent to or connected by key communication lines with influential suppliers of energy resources. However, at the same time, this region, as well as its neighbors, is a zone of increasing importance and tension, and sea routes are high-risk areas.

The position of Saudi Arabia as one of the leading players in the global energy market is determined by the richest resource and production base. Saudi Arabia is the third-largest 
producer (12.3\% of world total) and the first net exporter of crude oil, and the ninth producer of natural gas [63]. It produces a third of OPEC's oil and has remained the leader of the bloc since the 1990s [73]. Saudi Arabia's economy is highly dependent on oil revenues, which allow realizing an ambitious national program on social and economic reforms. However, oil and gas remain the backbone of Saudi Arabia's development. Saudi Arabia's decisions on energy have a geopolitical aspect and impact the global energy market in general.

In the EU, technological progress and a consistent policy of energy conservation have made it possible to grow with practically stable energy consumption. Correlation between economic development and the growth of energy consumption has been severed: on average, during $1995-2006,1 \%$ of GDP growth required $0.4 \%$ growth in energy consumption; after the economic crisis (on average for 2010-2015), GDP growth by $1 \%$ occurred with a decrease in energy consumption by $0.4 \%$ [74]. Thus, trends in the European energy market have a significant meaning for the long-term planning of EU's partners, and the energy transition to a carbon-free economy is the most important one.

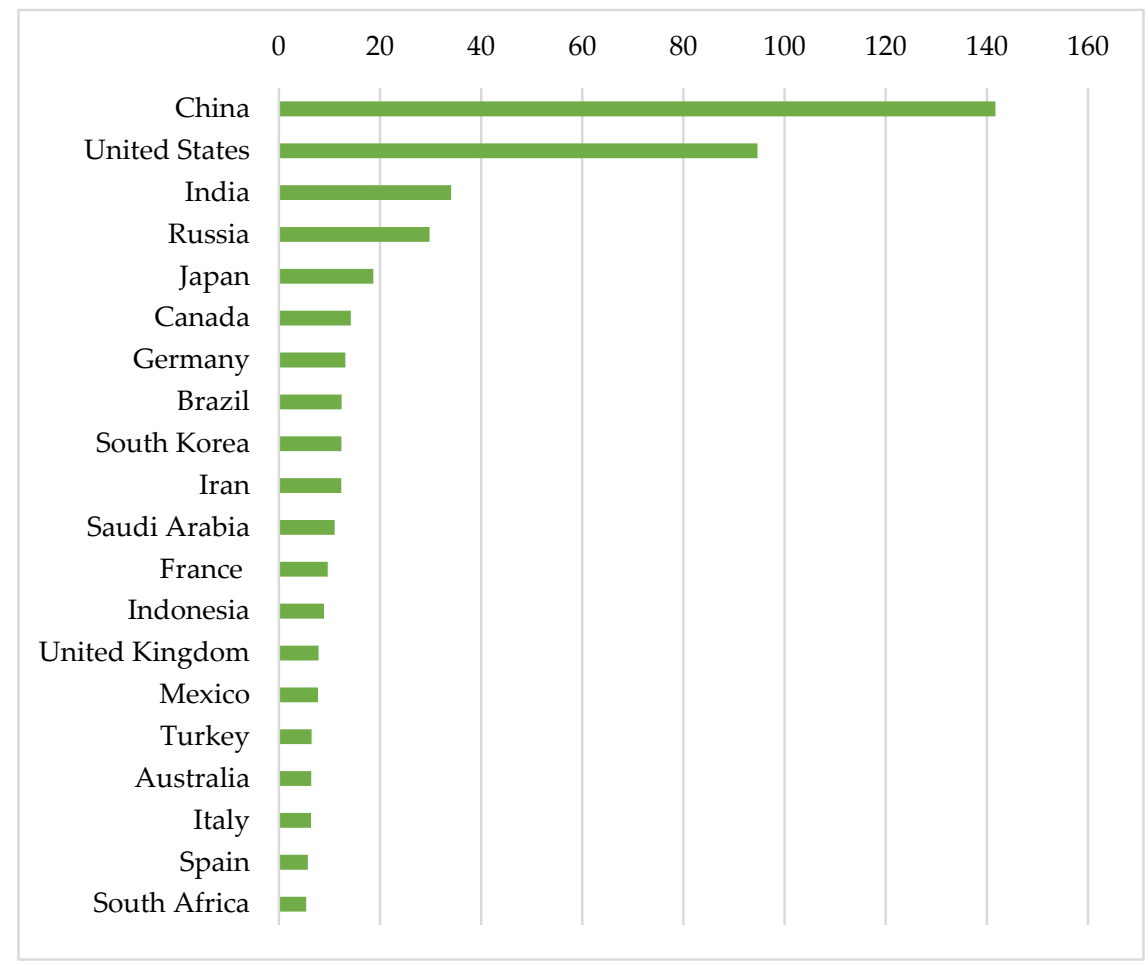

Figure 1. Leading countries in primary energy consumption worldwide in 2019 (in exajoules). Resource: Statista, 2020 [75].

China produced $48 \%$ of the world's coal in 2018 (46.6\% in 2019) and $28 \%$ of hydro [76]. The United States is the world's largest producer of nuclear power $(30 \%$ of worldwide nuclear generation of electricity) [77]. Russia and the United States contributed $40 \%$ of the world's natural gas [76]. The United States consumed about $16 \%$ of the global energy, China-22\%, India-6\%, and Russia-5\% [76]. Both Russia and Saudi Arabia are key actors to influence the oil market and prices. Decisions of two key players in the coal market-China and India-largely define the coal trade. In summary, all selected countries and one supranational union are game changers in the global energy market. They are large producers and consumers in the global energy market, but more important is that the decisions and agreements that these countries make have a profound impact on the global energy trade. Their energy transition will have a profound impact on the global system. 


\subsection{Identification of Energy Transition in National Energy Strategies}

This part describes the six priority cases chosen above. Data were derived from different sources, including official government and international organizations' documents, statistics, and plots of reputable media. We analyzed strategic documents of selected stakeholders in the energy sphere or closely related areas. In some cases, there is no single strategy and we have considered several documents. The phrase "strategic documents" is used as an umbrella term for different kinds of official documents (strategies, plans, decrees, etc.) that set out the strategic vision, reflect priorities and goals in the development of the energy sector, identify challenges, define the role of energy transition, and determine key technological priorities.

\subsubsection{Russia}

Russia recognizes the inevitability of change and responds to the ongoing global trends, supporting the development of renewable energy and hydrogen projects. The country's energy balance is quite efficient: $50 \%$ of natural gas, $19 \%$ of nuclear generation, $18 \%$ of hydro generation, and $1 \%$ of renewable energy sources, the share of which is to grow to $4 \%$ [78]. However, a conviction that the consumption of hydrocarbons will remain high even after 20 years prevails. The base document for Russia's policy in the energy sphere, Energy Strategy to 2035 [64] defines the turn of the 2030-2040s of the 21st century as a time horizon of the profound transformation of the world energy sector, which will affect the energy mix and technological base of the sector. Large-scale changes in the Russian energy sector are due to two main reasons. Firstly, Russia is a major producer, consumer, and exporter of all types of carbon energy resources and one of the world leaders in nuclear energy and hydropower. Secondly, the energy complex takes a central position in the country's economy, plays a role of basic infrastructure, and is a basis for budget revenues.

Interconnection between the country's socioeconomic development and energy sector creates the necessity for a transition to a more efficient, sustainable, and flexible energy complex, which implies structural diversification (supplementing carbon resources with non-carbon and complementation of raw materials export with Russian equipment, technologies, and services), digital transformation, optimization of the spatial distribution of the energy infrastructure (including transport), reducing the negative environmental impact, and adaptation to climate change. These define the main priorities of the state energy policy: guaranteed energy safety and security, ensuring domestic energy demand, transition to an environmentally friendly and resource-saving energy complex. In the context of price and demand volatility, the importance of strategic planning, anti-crisis, and risk-based management is rising.

The strategy highlights that the development of domestic and global markets of energy products and services, international politics, and economic context will be taken into account during this transformation. Thereby, the importance of the geopolitical component in the modern energy sphere is recognized. This is confirmed by the emphasis on the necessity to achieve technological independence-previously perceived as an advantage, today close interconnections in the global economic system, as well as a division of labor, are considered as a possible vulnerability in the case of rising political tension. For instance, the strategy assumes a systematic transition to using domestic automatic control systems and software at critical infrastructure and facilities of the energy complex.

The second stage of the strategy (2025-2035) involves a transition to the new generation energy complex, based on advanced technologies, highly efficient use of traditional energy resources, unconventional hydrocarbons, hydrogen, and other alternative sources. The strategy defines technologies of gas hydrate and oil source rock development as breakthrough technologies, capable of causing a significant redistribution of the global energy markets. Renewables and energy storage, electric and hybrid vehicles, including hydrogen, automated and connected transportation technologies; electric grid technologies, including active-adaptive power grids and distributed generation; energy-efficient technologies in residential, commercial, and administrative buildings; and information technology plat- 
forms for planning (forecasting) and energy infrastructure management are technologies that which will contribute to the energy transition.

A stable and reliable supply of domestic demand for the products and services of the energy sector is expected to be a result of the strategy implementation. At the same time, the transformation of the branches of the energy complex is to make a significant contribution to the reduction in the economy's energy intensity. The Russian Federation will maintain its position in the top three world leaders in energy production and trade, while significantly increasing the flexibility of export policy due to geographical and product diversification of export, including the export of Russian technologies, equipment, materials, and services.

In the Economic Security Strategy of the Russian Federation until 2030 [79], the energy transition was not mentioned directly. However, given the global energy trends, the strategy defines a comprehensive development of the energy infrastructure, the use of perspective energy-efficient technologies, and the increase in process efficiency and export diversification as one of the main tasks for ensuring sustainable growth of the real sector of the economy.

The strategy for the development of the mineral resource base until 2035 [80] assumes the development of advanced extraction and processing technologies and new infrastructure building. The transition of the country's economy to a new technological mode will be ensured by the products and infrastructure of the mining and energy industries, especially in less developed regions.

Russia's plans to work in the Arctic, a strategically important and complex region due to the collision of interests of several stakeholders, reflect the priority of the national interests and pragmatic approach. The Strategy for Developing the Russian Arctic Zone and Ensuring National Security through 2035 [81] involves state support for investment in energy infrastructure and its development, comprehensive development of the territories, ensuring energy security of settlements in the basin of rivers Yana and Indigirka, and development of the Krasnorechenskoye coal deposit.

Russia is a traditional guarantor of national and global energy security; to maintain its position on international energy markets and further socioeconomic development, Russia runs the active construction of energy infrastructure, including natural gas processing plants and renewable energy facilities, improves the conditions for domestic processing of raw materials, and production of high-end products [65]. Stimulation of development and implementation of domestic advanced energy technologies and use of renewables and environmentally friendly resources is aimed to provide domestic supply and bring the country to new high-tech markets.

In October 2021, Russia adopted the 2050 Strategy of Social and Economic Development with Low Greenhouse Gas Emission [82]. The document focuses on the climate agenda and the negative effects of climate change. It assumes two possible development scenarios-inertial and intensive. The first one provides the implementation of already approved decisions to achieve national goals and objectives of sectoral strategic documents; then in the second, the energy transition is considered as one of the factors ensuring the competitiveness of the Russian economy worldwide. The intensive scenario focuses on technological trends to decarbonize the economy and ensure economic growth.

\subsubsection{China}

Change of priorities in domestic policy, as well as events of international climate negotiations and changes in the global energy market have had a significant impact on China's energy policy. A slowdown in the growth of the national economy promoted an acceptance of the official course towards the development of domestic consumption, expansion of the service sector and focus on innovation, and implementation of the reforms in financial, tax, and social spheres. Environmental pollution has been recognized as a national issue, affecting the quality of life-a target to limit coal consumption and to increase the use of clean energy resources has been recognized as an urgent task in the economic development plans [83]. 
While analyzing China's energy policy, the following documents should be taken into account: the blueprints of the 14th Five Year Plan (for 2021-2025) and 2035 vision (2021-2035), the Energy Supply and Consumption Revolution Strategy (2016-2030), and the Guidance on the Promotion of Energy Storage Technology and Industry Development.

China is expected to implement a series of plans for low-carbon development to reach peak carbon emissions by 2030 and become carbon neutral by 2060. The last goal was set out by President Xi Jinping in September 2020. It allows to provide a suggestion on the areas that will be supported:

- $\quad$ Green finance, green technology, green production facilities;

- Environmental protection industries;

- Green transformation of key industries;

- Clean, low-carbon, safe, and efficient use of energy;

- Green buildings;

- $\quad$ Green life creation activities [84].

Despite the bold plans and five key development concepts: innovation, coordination, greenness, openness, and sharing, experts argue that China's energy policy will rely on progress, which is the overarching theme of the plan, while maintaining stability; selfsufficiency and boosting domestic demand become more pronounced themes [84]. Given the size of China's economy and the amount of needed energy, it is reasonable to assume that the 14th Five Year Plan is to be aimed to reduce greenhouse gas emissions while maintaining stable economic development at the expense of technological innovation.

The Energy Supply and Consumption Revolution Strategy (2016-2030) [85] highlights that China's energy strategy is entering a new stage of development, associated with qualitative improvements rather than a quantitative capacity increase. The strategy reflects the necessity to formulate long-term goals of sustainable development and take into consideration the limitations of natural resources and increasing pressure on the environment. Below are some objectives the strategy sets out, which allow identifying foreground directions of technological development:

- $\quad$ Meeting increasing demand through clean and sustainable energy;

- Increase in the non-carbon sources and natural gas to $20 \%$ and $15 \%$ of energy consumption by 2030, respectfully;

- $\quad$ Bringing energy sufficiency of industrial production to the highest world indications;

- Development of energy-saving technologies and equipment;

- $\quad$ Reduction in pollution through the use of carbon management systems;

- Development of low carbon products certification, green production, and green supply chains;

- $\quad$ Enlargement of the environmentally friendly transport system;

- Development of online environmental monitoring;

- Development of smart cities, buildings, and household appliances;

- Acceleration of development of large-scale onshore and offshore wind power systems;

- Development of highly efficient technologies and equipment for solar energy generation and development of hybrid solar-wind energy generation;

- Use of advanced nuclear energy technologies (including floating nuclear power stations and pollution control technologies);

- Development of technologies for exploration and exploitation of deep deposits;

- $\quad$ Research on superconductors and superconducting materials, wireless power transmission technologies, and solid-state transformers;

- Development of carbon capture and storage technologies.

In the Guidance on the Promotion of Energy Storage Technology and Industry Development [86], energy storage is described as a key support technology of the smart grid; it can significantly improve the absorption level of renewable energy and support distributed power and microgrids. Energy storage is a key technology to raise the share of renewable energy in the country's energy balance. The guidance suggests the focus on research, 
promotion, and adaptation of energy storage technologies. It is worth noting that China does not favor renewables as a source that will completely replace fossil fuels.

Overall, the content of all documents offer a look at priorities, challenges, and opportunities, and suggests already existing and, to some extent, developed directions that will be in priority: high-quality growth instead of high-speed growth, expanding domestic demand, innovation, and technological advancements, promoting high-end, intelligent, and green production, and green and low-carbon development. Long-term goals are tech-oriented and self-reliance in science is strategic support for national development. It is extremely important to note that despite the announcement of policy towards carbon-neutrality by 2060 and oil and natural gas consumption reduction by $65 \%$ and by $75 \%$, respectively, any restriction in the use of coal in the short term has not been announced. This confirms the priority of domestic steady development and reliance on the real situation in the economy (in 2019, 58\% of all energy came from coal). There is no fixed goal for China's GDP in the blueprints of the 14th Five Year Plan (for 2021-2025) and 2035 vision (2021-2035), but the Proposals for Formulating the 14th Five Year Plan (2021-2025) for the National Economic and Social Development and the Long-Range Objectives Through the Year 2035 set the goal for per capita GDP to match that of "moderately developed nations" by 2035. As there is no generally accepted definition of "moderately developed nations", Chinese experts, based on the classification of international organizations, interpret "moderately developed nations" as having a per capita GDP of USD 20,000 to USD 40,000 [87]. It will require China to maintain real growth at an average of $3.6 \%, 4.8 \%$, or $5.4 \%$ (depending on the calculations used) over the coming 15 years [87]. This is a quite high indicator for a long period, requiring a powerful drive for development.

\subsubsection{USA}

In the United States, energy policy is considered to be closely related to national security policy and foreign policy. A key goal of the United States energy policy is to ensure energy security and energy self-sufficiency. Achieving a central position in the global energy system is one of the priorities outlined in the National Security Strategy 2017 [88]. The use of different energy resources (coal, natural gas, oil, renewables, and nuclear energy) is described as a stimulus for economic development. The strategy emphasizes that the United States is committed to supporting energy initiatives aimed at protecting the environment and strengthening the country's energy security, but does not support programs aimed at curbing growth-"anti-growth energy agenda that is detrimental to U.S. economic and energy security interests". Therefore, measures to reduce pollution during extraction and the use of conventional energy sources should not constrain economic growth.

No less important is the remark that much of the developing world will require fossil fuels as well as other forms of energy to develop their economies. It is undeniably interconnected to the remark about America's central position as a "leading producer, innovator and consumer" in the global energy sphere. Given this, according to the strategy, the United States is going to advance an approach that balances energy security, economic development, and environmental protection.

The strategy envisages the strengthening of nuclear technologies, next-generation nuclear reactors, better batteries, advanced computing, carbon-capture technologies, and opportunities at the energy-water nexus. The strategy outlines the need for understanding worldwide technology and market trends and how they are to influence American programs. According to the Energy Storage Grand Challenge Roadmap, a global focus on energy storage solutions and grid flexibility services offers the United States an opportunity to create and sustain its leadership in energy storage [89].

It is necessary to take into account the American nuclear energy strategy-Restoring America's Competitive Nuclear Energy Advantage-which is a strategy to assure U.S. National Security [90]. To ensure a clean, sustainable, and reliable nuclear power the strategy suggests: (1) improvement of uranium mining industry, uranium conversion services; (2) leveraging technological innovations and investment to reestablish U.S. leadership in 
next-generation nuclear technology; enabling uranium mining companies, fuel cycle participants, and reactor manufacturers to offer their products and services; and (3) recovering position as a world leader in exporting best-in-class nuclear energy technology.

As the United States considers energy as an instrument of its foreign policy, it will take into account energy balance and widespread sources in the markets regarded as strategic directions. For instance, according to the European Energy Security and Diversification Act of 2019, the policy of the United States includes help for facilitation of the export of United States energy resources, technology, and expertise to global markets in a way that benefits the energy security of European countries. The U.S. is to assist projects related to energy infrastructure and facilities, including renewables [66]. The enhancement of European energy security and diversification of energy sources and supply routes will help the United States to ensure its economic and national security interests.

It is important to note a major shift from the previous policy and the change in the rhetoric of the political establishment after the change of presidential administration in 2021. The approach to the energy issue as a national security policy and foreign policy objective is still relevant but from a different perspective. Today, climate change issues and acceleration of energy transition take one of the central parts in the U.S. foreign policy. If the previous administration emphasized the priority of domestic development and pursued U.S. "energy independence" by rolling back from several climate regulations (considered as harmful for national economy), the current administration's energy policy consists of combating climate change and re-establishing the U.S. global leadership in key sectors of the future low-carbon economy [91].

Several executive orders aimed at decarbonization efforts of economic sectors have been signed. The question is whether energy policy continuity will remain after the change of administration. The environmental agenda was one of the key themes of the current president's election program, which was opposed to the course then pursued.

\subsubsection{Kingdom of Saudi Arabia}

Saudi Arabia has an oil-based economy; the petroleum sector accounts for more than $50 \%$ of budget revenues-in 2020, oil revenues were estimated at SAR 110 bn while all revenues-at SAR 205 bn [92]. Saudi Arabia's Vision 2030 sets the goal of diversifying the economy, including unlocking the underdeveloped renewable energy industry. One of the vision's pillars is a "thriving economy", that assumes doubling the gas production, construction of a national distribution network, and the use of expertise in oil and petrochemicals in investment in the development of adjacent and supporting sectors [93]. Vision 2030 aims to cut the Saudi Arabian economy's dependence on oil. As a part of the vision, the National Industrial Development and Logistics program sets the goal to increase the share of the renewable energy sector in local consumption while the global energy landscape is changing and increasing capital availability and volatile landscape contributions to reducing the value of energy and capital usually considered as the country's strengths [93]. By 2030, Saudi Arabia aims to produce 58.7 GW of renewable energy, of them, $40 \mathrm{GW}$ are from solar power [94].

The program outlines five key elements of the energy sector transformation:

- Foster power efficiency through conducting awareness campaigns, including the development of standards, and pursuing power and electricity saving initiatives;

- $\quad$ Increase the renewable energy share in the energy mix;

- Substitute diesel generators;

- Maximize value-added sector via increasing export to GCC countries and establish criteria to support local manufacturers;

- $\quad$ Set roles and responsibilities between various sector players.

Transformation of the energy sector creates opportunities to develop renewable energy equipment manufacturing that can serve both national and regional demand. Saudi Arabia has three competitive advantages to produce renewable energy equipment: strong solar and wind energy potential, sizeable regional market, and cost competitiveness in manu- 
facturing certain components of renewable equipment locally because of lower transport cost and existing or future value chains. One more perspective direction of technological development is carbon capture, utilization, and storage [93]. Under Saudi Arabia's G20 presidency, the pillar "Remove" has been included in the Circular carbon economy framework along with reduce, reuse, and recycle [95].

While declaring the plan of the energy system transformation, Saudi Arabia pursues a pragmatic approach. In accordance with Saudi officials, the energy transition is a "multi-decade process" and "needs all energy sources" to not disrupt the global economy [96]. According to some estimates, the country has more than 50 years of recoverable reserves [97,98]; given the development of renewable energy and transition to a carbonneutral economy, it is a matter of time how soon these reserves can become an impaired asset and time to get the maximum benefit from conventional energy sources is limited. There were several cues towards a shift to energy revenues maximization: in December 2019, Saudi Aramco had its first initial public offering, which is a way to monetize the initial value of oil reserves and to raise funding for the Vision 2030 implementation; Saudi Arabia has reached an agreement with Kuwait on the shared Neutral Zone to resume production from the oilfields; and in February 2020, investments were approved to develop al-Jafurah, the biggest unconventional gas field in the country.

\subsubsection{India}

As India's economy grows, energy consumption will rise; according to current policy, affordable and reliable energy countrywide access with the focus on electricity and clean cooking is one of the factors of socioeconomic transformation. The roadmap "Energy transition to fuel India's growth path" emphasizes that the energy sector should be growth-centric, industry-friendly, and environmentally conscious [99]. The countries energy security is fixed in the Self-reliant India Scheme (Aatmanirbhar Bharat) [100]; key areas of the energy agenda include:

(1) Intensifying efforts to transition to a gas economy;

(2) Cleaner use of fossil fuels;

(3) Expanding of production and use of biofuel;

(4) Expanding the use of renewable energy sources;

(5) Increasing the role of electricity, including the decarbonization of the transport system;

(6) Use of the new types of fuel, including hydrogen;

(7) Digitalization of the energy system.

The country's energy sector is oriented towards growth but takes into account the need to protect the environment. For this reason, renewable energy sources are actively developing. Thus, one of the directions of the Make in India [101] initiative is to attract international companies to the production of solar photovoltaic modules, lithium batteries, infrastructure for charging solar batteries, and other technologies for the energy system.

According to the National Electricity Plan until 2027 [102], the energy transition will be carried out with consideration of the realities of the country's economic development-the transformation of the electric power sector will take place not only through the development of carbon-free energy but also through the introduction of new technologies for the efficient use of traditional energy sources, including coal generation technologies. Traditional sources are of critical importance to the country's energy sector today. For instance, coal accounts for $70 \%$ of power generation, while solar is $4 \%$ [103]. Meanwhile, the government set the target of reducing import dependence, which means decreasing shares of fossil fuels [104].

Solar and wind energy are distributed sources, weather dependent, and cannot be centrally controlled. The challenges are related to the integration of renewable energy sources into the national electric power system, the impact of renewable energy on existing and planned coal power plants, and the introduction of microgrids and smart grids. Experts of India's Council on Energy, Environment and Water, highlight the importance of grid integration and storage solutions to address the supply variability of renewable energy 
generation [105]. In addition, government support is vitally important for the underway energy transition. In the wake of the COVID-19 pandemic in 2020, subsidies for renewable energy fell by $45 \%$ from the fiscal year 2017 peak, and the support for fossil fuels increased up to 7.3 times more than for clean energy in FY 2020 (seven times more in FY 2019). A total of $34 \%$ of subsidies go to fossil fuels [105].

Natural gas will play an important role in India's energy transition. In 2021, India committed to achieving $15 \%$ share of gas in a more sustainable energy mix by 2030 [106] (6.3\% today [107]). The necessary condition is an expansion of gas pipeline infrastructureas of September 2020, the total length of natural gas pipelines was 32,559 km of which $15,543 \mathrm{~km}$ was under construction [108]. Gas-infrastructure projects are considered as a part of COVID-19 recovery efforts; the movement to a gas-based economy is one of the key points of the roadmap "Energy transition to fuel India's growth path" as well as cleaner use of fossil fuels, and greater reliance on domestic sources.

\subsubsection{The European Union}

European energy policy is unique. Impressive results have been achieved in the deployment of renewable energy infrastructure and increasing their share in the energy mix (we do not assess how this was done and with what results). Moreover, the European Union made the energy agenda an instrument of foreign policy [109]. The EU differs from other selected cases both in ambitiousness and scale of tasks and in the presence of an extensive regulatory framework. Below, we reviewed just a few of the key documents.

In 2011, the European Union set a target to achieve an emission level $80-95 \%$ below 1990 levels by 2050. Some of the key points of The Energy Roadmap 2050 [110] are the following:

- $\quad$ Higher energy efficiency is a main priority of the decarbonization scenario;

- $\quad$ The role of local organizations and cities will be much greater in the future energy system, thus it requires incentives to change behavior, such as taxes, grants, and on-site advice by experts;

- Further development of renewable and storage technologies to bring down costs;

- Gas plays a key role in the transition;

- Coal and oil are likely to remain in the energy mix even in 2050;

- $\quad$ Secure and safe nuclear energy is a decarbonization option;

- Development of new ways to manage electricity.

It is worth noting that the roadmap also pays attention to factors, which are difficult to predict and access, such as: oil peaks, the viability of shale gas, commercial success of some technologies (for instance, CCUS), the role of nuclear power, evolution of climate action, and other social, technological, and behavioral changes.

The Energy Roadmap was issued in 2011 and since then goals have become more ambitious and bolder. The European Parliament approved the net-zero greenhouse gas emissions goals in the resolution on climate change in 2019 [111] and the resolution on the European Green Deal in 2020 [112]. It sets the target of turning Europe into the first climateneutral continent by 2050; to get there, member states pledged to reduce emissions at least $55 \%$ below 1990 levels by 2030 [113]. According to the Green Deal, renewable sources should account for $40 \%$ of the energy mix in 2030 . Green Deal incorporates energy and climate targets in the growth strategy; energy and environment are infrastructure-intensive sectors and can contribute to sustainable development. Thus, this approach can help to improve quality of life, support industrial modernization, and attract investments [109]. The green transition should be supported by the tax system for energy products to mitigate the social impact. To meet climate and energy targets for 2030, member states are required to set 10-year national energy and climate plans for 2021-2030.

National plans and the EU's strategy should cover the following issues [114]:

- Total greenhouse gas emission reductions;

- Emission reductions in sectors, including electricity, industry, transport, the heating and cooling and buildings sector, agriculture, and waste and land use, etc. 
- $\quad$ Expected progress on transition to a low greenhouse gas emission economy;

- Expected socioeconomic effects of decarbonization measures;

- Links to other national long-term objectives and planning, including investments.

Despite ambitious goals, oil and gas remain the dominant fuels in Europe [115,116]; only Austria, Belgium, and Sweden moved away from coal. In the 2000s, the growth of the renewable energy sector was supported by the development of industry and domestic markets. The share of RES rose from $6.4 \%$ of the EU's energy mix in 2000 to $15.8 \%$ in 2019 [115], and in 2020 both demand for renewable technologies and renewable energy capacity increased despite COVID-19. The shortage of electricity in winter 2021 forced a turn to fossil fuels, however, already there is both a physical reduction in generating capacity and a rising cost of carbon credits.

The energy crisis of 2021 will probably affect the timing of achieving the EU's declared goals; by declared deadlines, the real pace of energy transition will become clear. Renewable energy sources are not able to become a backbone of the energy generation system, at least not now. An energy system needs reserve capacities as well as technologies that would minimize the negative consequences of failure of generating capacities, including unforeseen ones. Without it, the rising share of RES in the energy system boosts instability of the system itself.

\section{Results and Discussion}

\subsection{Results}

Case studies allowed us to define energy priorities in the context of economic development (Table 4), key directions for future transformation, and selected countries' approaches to the energy transition. These approaches can be conditionally divided into ideological and pragmatic.

Table 4. Key features and energy priorities of selected country cases.

\begin{tabular}{|c|c|c|c|}
\hline Case & $\begin{array}{l}\text { Role of Energy Complex in } \\
\text { the National Economy }\end{array}$ & Position on Fossil Fuels & Energy Transition Priorities \\
\hline Russia & Central position & $\begin{array}{l}\text { Consumption of fossil } \\
\text { fuels will remain high } \\
\text { even after } 20 \text { years }\end{array}$ & $\begin{array}{ll}- & \text { Socioeconomic development } \\
- & \text { Diversification of budget revenues } \\
- & \text { Achievement of tech independence }\end{array}$ \\
\hline China & $\begin{array}{l}\text { Driver of economic } \\
\text { development }\end{array}$ & $\begin{array}{l}\text { Backbone of } \\
\text { energy system }\end{array}$ & $\begin{array}{ll}\text { - } & \text { Emphases on domestic development (dual circulation strategy) } \\
- & \text { Reduction in environmental pollution } \\
\text { - } & \text { Resource and technology self-reliance }\end{array}$ \\
\hline United States & $\begin{array}{l}\text { Energy policy is closely related } \\
\text { to the national security policy } \\
\text { and foreign policy }\end{array}$ & $\begin{array}{l}\text { Energy comes mostly from } \\
\text { fossil fuels }\end{array}$ & $\begin{array}{ll}\text { - } & \text { Strengthening energy security and energy self-sufficiency } \\
\text { - } & \text { Environmental protection }\end{array}$ \\
\hline Saudi Arabia & Oil-based economy & $\begin{array}{l}\text { Retirement from fossil } \\
\text { fuels-multi- } \\
\text { decade process }\end{array}$ & $\begin{array}{ll}\text { - } & \text { Economic diversification } \\
\text { - } & \text { "Thriving economy" } \\
\text { - } & \text { Development of renewable energy equipment manufacturing }\end{array}$ \\
\hline India & $\begin{array}{l}\text { Driver of economic } \\
\text { development }\end{array}$ & $\begin{array}{l}\text { Traditional energy sources } \\
\text { are of critical } \\
\text { importance today }\end{array}$ & $\begin{array}{ll}\text { - } & \text { Socioeconomic development } \\
\text { - } & \text { Affordable and reliable energy countrywide access } \\
\text { - } & \text { Environmental protection }\end{array}$ \\
\hline European Union & $\begin{array}{l}\text { Vital to many sectors of } \\
\text { the economy }\end{array}$ & $\begin{array}{l}\text { Lower fossil } \\
\text { fuels dependence }\end{array}$ & $\begin{array}{ll}\text { - } & \text { Secure, competitive, decarbonized energy system } \\
\text { - } & \text { Secure energy supplies } \\
\text { - } & \text { Sustainable energy consumption }\end{array}$ \\
\hline
\end{tabular}

Resource: compiled by the authors.

Considering information on development priorities, the role of fossil fuels in the energy balance, the level of technological development, and the stated goals for the energy transition, it is possible to conditionally divide the countries' approaches to the energy transition into "pragmatic" and "idealistic" ones. The first is characterized by the priority of socioeconomic development and needs of the population through the gradual introduction of clean technologies and the transition to carbon neutral energy generation. The second emphasizes achieving carbon neutrality. All considered countries are taking measures for 
the energy transition, but the motives, pace, and priorities differ. Moreover, it is necessary to consider the barriers that already exist or may arise in the future, including unexpected events, which could slow down the energy transition (Table 5).

Table 5. Existing and potential barriers of energy transition.

Examples of Barriers
Rapid population growth
Public perception of green technologies and renewables
Lack of public support
Changing social behavior
Pandemics
Inappropriate level of technological development
Obsolete infrastructure
Inconsistency of renewable power generation
Lack or scarcity of capacity storage and management
The unresolved issue of interaction between intermittent and dispatchable
sources of power
Substantial/rapid increase in rare earth metals prices
Economic sectors' dependence on fossil fuels
Low population income
Lack of investment
High price of green technology
Unresolved issue of green technologies commercialization
Highly controlled energy sector
Restricted access to technologies
Trade barriers
High payback period
Small internal market
Energy crisis
Lack of political will
Use of access to advanced technology market as a political tool
Clash of interests
Weather and climate risks
Renewables' dependence on weather regimes
Limited reserves of rare earth metals
Lack of disposal and recycling facilities

Resource: compiled by the authors.

None of the cases can be categorized unequivocally. They can be approached by a ranking scale with two poles-"pragmatic" and "idealistic" and intermediate states. Even the European Union, with its Green Deal, which has become a foreign policy tool, cannot be indisputably attributed to the "idealist group", although the EU is the closest to this category. Yet in developed countries, the authorities cannot sacrifice socioeconomic development and do not pay attention to voters' preferences. Moreover, as the migration situation is getting worse, internal issues related to the fair distribution of social benefits are exacerbated, which means rising pressure on budgets. The 2021 energy crisis made it obvious that retirement from hydrocarbon was premature. At the opposite end of the scale are Saudi Arabia, China, and India. Russia can conditionally be assigned an intermediate position due to the large share of hydro and nuclear energy in the energy balance and confirmation of a strong interest in a green agenda. The United States can be called a "drifting" country, where the energy agenda is closely related to the peculiarities of the domestic political system and foreign policy course. What brings the EU and the U.S. closer together is that they actively use the energy and climate agendas as foreign policy instruments. 
The highlighted barriers are general and relevant for the selected cases to varying degrees. Some of them may be classified as wild cards, for example, pandemics, weather, or climate risks.

\subsection{Discussion}

The purpose of this paper was to draw attention to the specific "starting" conditions for the energy transition and to show the existence of many approaches and the decisive role of political will, based on the realities of socioeconomic and technological development in sound decision making. The established deadlines for achieving certain targets can be changed (as well as the targets themselves) due to the peculiarities of development or unpredictable events. Thus, the forecasts of international organizations are rather advisory in nature and depict one of the possible (ideal) options for the future.

Several questions remained unanswered. The following themes indicate where the study can be expanded. Primarily, identified priorities and existing and potential barriers presented in the previous section can be used as a basis for further study of energy transition policies of different countries and determination of the vectors of their future development, as well as their place in the global energy system. It can be approached by foresight methodology and scenario analysis.

Taking into account the strong political component and states' focus on internal agendas, it can be assumed that the issues of the energy transition will have a severe impact (negative or positive) on bilateral and multilateral relations. The issues of interaction of actors on the world stage, in particular in such an important strategic region as the Arctic, were considered casually. However, among the selected cases, Russia and the United States are members of the Arctic Council and China (!) officially considers itself a "near-Arctic state". In 2021, the European Union called to stop any further hydrocarbon reserves development in this part of the world. As the energy transition concept and green agenda are closely related, stakeholders' politics toward such a strategic region can be studied. Moreover, long-term obligations of exporting countries to external parties are worth considering as a longer influence factor. Besides, countries can be classified by their level of development, and grouped as high-income, middle-income, and low-income. Moreover, national strategies can be analyzed for wild cards.

The analysis can be deepened by correlating the identified barriers and those that are highlighted in national politics. Based on the data obtained, further courses for the development of the energy sector and related economic, $R \& D$, and environmental protection can be formed.

\section{Conclusions}

Currently, the problem of the energy transition is of vital importance in light of the social and economic problems aggravated during the pandemic. In this regard, it attracts the attention of national governments, academic communities, and businesses. According to Grubler [4], the necessity of the next energy transition takes place as the current energy system does not cope with all environmental, social, and economic issues. York and Bell [5] suggest distinguishing two concepts-"energy transition" and "energy addition", emphasizing qualitatively different natures of these processes. In this paper, the term "transition" is used while meaning gradualness of the process.

Given the importance of the relationship of the energy sector with social and economic dimensions, the paper provided examples of social and economic challenges associated with the energy sector, as well as potential barriers to the energy transition. Based on this, we highlight that the state policy plays a profound role in the energy sector transformation because of its importance for the country's economic development and national security, which correlates with the provisions given by Blazquez, Fuentes, and Manzano [26]. We suggest that the increased focus of states on the domestic agenda during the pandemic is a long-term trend. This justifies the importance of analyzing national energy plans and strategies. 
Selected case studies showed the correctness of the position that each case of the energy transition is unique and is determined by the national energy policy based on peculiarities of the country's socioeconomic and technological development. Moreover, the paper proposes that current and future barriers, i.e., wild cards, may influence the process of energy transition and should be taken into account when considering individual energy trajectories.

Author Contributions: Conceptualization, D.G.; methodology, Y.M.; writing—original draft, D.G.; writing-review and editing, Y.M. All authors have read and agreed to the published version of the manuscript.

Funding: The article is based on the study funded by the Basic Research Program of the HSE University.

Institutional Review Board Statement: Not applicable.

Informed Consent Statement: Not applicable.

Data Availability Statement: Not applicable.

Acknowledgments: The authors gratefully acknowledge the support of the HSE University, Russian Federation.

Conflicts of Interest: The authors declare no conflict of interest.

\section{References}

1. UN. Sustainable Development Goal 7. 2015. Available online: https://sdgs.un.org/goals/goal7 (accessed on 13 November 2021).

2. UN. United Nations Conference on New and Renewable Sources of Energy in Nairobi. 1981. Available online: https:// digitallibrary.un.org/record/157485? ln=ru (accessed on 13 November 2021).

3. Solomon, B.D.; Krishna, K. The coming sustainable energy transition: History, strategies, and outlook. Energy Policy 2011, 39, 7422-7431. [CrossRef]

4. Grubler, A. Energy transitions research: Insights and cautionary tales. Energy Policy 2012, 50, 8-16. [CrossRef]

5. York, R.; Bell, S.E. Energy transitions or additions?: Why a transition from fossil fuels requires more than the growth of renewable energy. Energy Res. Soc. Sci. 2019, 51, 40-43. [CrossRef]

6. Kuzemko, C.; Bradshaw, M.; Bridge, G.; Goldthau, A.; Jewell, J.; Overland, I.; Scholten, D.; Van de Graaf, T.; Westphal, K. Covid-19 and the politics of sustainable energy transitions. Energy Res. Soc. Sci. 2020, 68. [CrossRef]

7. Kuzemko, C. Re-scaling IPE: Local government, sustainable energy and change. Rev. Int. Political Econ. 2019, 26, 80-103. [CrossRef]

8. Goldthau, A.; Westphal, K.; Bazilian, M.; Bradshaw, M. How the energy transition will reshape geopolitics. Nature 2019, 56, 29-31.

9. Pastukhova, M.; Westphal, K. Governing the global energy transformation. In The Geopolitics of the Global Energy Transition; Springer: Berlin, Germany, 2020; pp. 341-364. Available online: https:/ /link.springer.com/chapter/10.1007/978-3-030-39066-2_ 15 (accessed on 25 January 2021).

10. WEC. World Energy Trilemma Index 2020. 2020. Available online: https:/ / www.worldenergy.org/assets/downloads/World_ Energy_Trilemma_Index_2020_-_REPORT.pdf (accessed on 26 January 2021).

11. WEF. The Global Risks Report 2020. 2020. Available online: https://www.weforum.org/reports/the-global-risks-report-2020 (accessed on 25 February 2021).

12. PwC. Adapt-Five Urgent Global Issues and Implications. 2020. Available online: https://www.pwc.com/gx/en/issues/adapt. html (accessed on 25 February 2021).

13. WEF. Energy Transition Index 2020: From Crisis to Rebound. 2020. Available online: https://www.weforum.org/reports/ fostering-effective-energy-transition-2020 (accessed on 25 February 2021).

14. International Renewable Energy Agency. Global Energy Transformation: A Roadmap to 2050, International Renewable Energy Agency. Abu Dhabi, United Arab Emirates. 2018. Available online: https://www.irena.org/-/media/Files/IRENA/Agency/ Publication/2018/Apr/IRENA_Report_GET_2018.pdf (accessed on 25 January 2021).

15. WEC. Global Energy Transitions. A Comparative Analysis of Key Countries and Implications for the International Energy Debate. 2014. Available online: http://wec-france.org/DocumentsPDF/donnees/Global-Energy-Transitions-2014.pdf (accessed on 25 January 2021).

16. Markard, J. The next phase of the energy transition and its implications for research and policy. Nat. Energy 2018, 3, 628-633. [CrossRef]

17. Geels, F.W.; Sovacool, B.K.; Schwanen, T.; Sorrell, S. Sociotechnical transitions for deep decarbonization. Science 2017, 357, 1242-1244. Available online: https://science.sciencemag.org/content/357/6357/1242?rss=1 (accessed on 30 January 2021). [CrossRef] 
18. Markard, J. The life cycle of technological innovation systems. Technol. Forecast. Soc. Chang. 2020, 153, 119407. Available online: https: / / www.research-collection.ethz.ch/handle/20.500.11850/291404 (accessed on 2 March 2021). [CrossRef]

19. Child, M.; Koskinen, O.; Linnanen, L.; Breyer, C. Sustainability guardrails for energy scenarios of the global energy transition. Renew. Sustain. Energy Rev. 2018, 91, 321-334. [CrossRef]

20. Henderson, J.; Mitrova, T. Implications of the global energy transition on Russia. In The Geopolitics of the Global Energy Transition. Lecture Notes in Energy; Hafner, M., Tagliapietra, S., Eds.; Springer: Cham, Switzerland, 2020; Volume 73. [CrossRef]

21. Smil, V. Energy and Civilization: A History; MIT Press: Cambridge, MA, USA, 2017; Available online: https://books.google.ru/ books?id=Br74DwAAQBAJ\&printsec $=$ frontcover\&hl=ru\#v=onepage\&q\&f=false (accessed on 2 March 2021).

22. Henderson, J. The Energy Transition: Key Challenges for Incumbent and New Players in the Global Energy System; Oxford Institute for Energy Studies: Oxford, UK, 2021; Available online: https://www.oxfordenergy.org/wpcms/wp-content/uploads/ 2021/09/Energy-Transition-Key-challenges-for-incumbent-players-in-the-global-energy-system-ET01.pdf (accessed on 30 November 2021).

23. IEA. Net Zero by 2050. A Roadmap for the Global Energy Sector. 2021. Available online: https://www.iea.org/reports/net-zeroby-2050 (accessed on 30 November 2021).

24. Mazzeo, D.; Matera, N.; De Luca, P.; Baglivo, C.; Congedo, P.M.; Oliveti, G. Worldwide geographical mapping and optimization of stand-alone and grid-connected hybrid renewable system techno-economic performance across Köppen-Geiger climates. Appl. Energy 2020, 276, 115507. [CrossRef]

25. Chen, D.; Chen, H.W. Using the Köppen classification to quantify climate variation and change: An example for 1901-2010. Environ. Dev. 2013, 6, 69-79. [CrossRef]

26. Blazquez, J.; Fuentes, R.; Manzano, B. On some economic principles of the energy transition. Energy Policy 2020, $147,111807$. [CrossRef]

27. Hirsch, T.; Matthess, M.; Fünfgelt, J. Guiding Principles Lessons Learnt for a Just Energy Transition in the Global South. Friedrich Ebert Stiftung. 2017. Available online: http:/ / library.fes.de/pdf-files/iez/13955.pdf (accessed on 28 November 2021).

28. Edenhofer, O.; Pichs-Madruga, R.; Sokona, Y.; Seyboth, K.; Matschoss, P.; Kadner, S.; von Stechow, C. IPCC Special Report on Renewable Energy Sources and Climate Change Mitigation; Cambridge University Press: Cambridge, UK; New York, NY, USA, 2011.

29. Klemeš, J.J.; Van Fan, Y.; Jiang, P. COVID-19 pandemic facilitating energy transition opportunities. Int. J. Energy Res. 2020, 45, 3457-3463. Available online: https:/ / onlinelibrary.wiley.com/doi/10.1002/er.6007 (accessed on 30 November 2021). [CrossRef] [PubMed]

30. Jiang, P.; Van Fan, Y.; Klemeš, J.J. Impacts of COVID-19 on energy demand and consumption: Challenges, lessons and emerging opportunities. Appl. Energy 2021, 285, 116441. [CrossRef]

31. Sueyoshi, T.; Ryu, Y.; Yun, J.-Y. COVID-19 Response and prospects of clean/sustainable energy transition in industrial nations: New Environmental assessment. Energies 2021, 14, 1174. [CrossRef]

32. Lahn, G.; Bradley, S. How COVID-19 Is Changing the Opportunities for Oil and Gas-Led Growth. OECD. Development Matters. 2020. Available online: https:/ / oecd-development-matters.org/2020/07/10/how-covid-19-is-changing-the-opportunities-foroil-and-gas-led-growth/ (accessed on 30 November 2021).

33. Kulagin, V.; Grushevenko, D.; Kapustin, N. Fossil fuels markets in the "energy transition" era. Russ. J. Econ. 2020, 6, 424-436. Available online: https:/ / rujec.org/article/55177/ (accessed on 13 November 2021). [CrossRef]

34. Vedomosti. Vakcina dlya Rynka Nefti: Kak Bor'ba s Koronavirusom povliyaet na Ceny [Vaccine for the Oil Market: How the Fight against Coronavirus Will Affect Prices]. 2020. Available online: https://www.vedomosti.ru/business/articles/2020/11/23 /847975-vaktsina-dlya-rinka-nefti-kak-borba-s-koronavirusom-povliyaet (accessed on 25 November 2021).

35. The Russian Government. Alexander Novak Chairs OPEC and Non-OPEC Ministerial Meeting. 2021. Available online: http: / / government.ru/en/news/?dt.since=04.11.2021\&dt.till=04.11.2021 (accessed on 25 November 2021).

36. Nasdaq. Energy ETFs Rise as Crude Oil Prices Break Above \$80. 2021. Available online: https://www.nasdaq.com/articles/ energy-etfs-rise-as-crude-oil-prices-break-above-\%2480-2021-10-11 (accessed on 25 November 2021).

37. Bank of Russia. Monetary Policy Report N4. October 2021. Available online: https://www.cbr.ru/Collection/Collection/File/39 297/2021_04_ddcp.pdf (accessed on 29 November 2021).

38. Bloomberg. Brent Crude Headed for $\$ 120$ by End of June, BofA Says. 2021. Available online: https://www.bloomberg. com/news/articles/2021-11-01/oil-headed-for-120-in-a-matter-of-months-bank-of-america-says?sref=zFmdEBXN (accessed on 29 November 2021).

39. IEA. World Energy Outlook. 2020. Available online: https://www.iea.org/reports/world-energy-outlook-2020 (accessed on 30 November 2021).

40. IEA. Coal 2020. Analysis and Forecast to 2025. 2020. Available online: https://www.iea.org/reports/coal-2020 (accessed on 30 November 2021).

41. OPEC. Monthly Oil Market Report. November 2021. Available online: https://momr.opec.org/pdf-download/ (accessed on 1 December 2021).

42. Buli, N.; Chestney, N. On the Cusp of Europe's Winter Season, Gas Storage Hits 10-yr Low. Reuters 2021. Available online: https:/ / www.reuters.com/business/energy/cusp-europes-winter-season-gas-storage-hits-10-yr-low-2021-09-22/ (accessed on 30 November 2021). 
43. Lanshina, T. Kak vliyaet Pandemiya na Global'nyj Energeticheskij Perekhod v Mire I v Rossii [How Does the Pandemic Affect the Global Energy Transition in the World and in Russia] Economy Times. 2020. Available online: https://economytimes.ru/kursrulya/kak-vliyaet-pandemiya-na-globalnyy-energeticheskiy-perehod-v-mire-i-v-rossii (accessed on 27 November 2021).

44. The Bell. OPEK Uvidela Konec Epohi Nefti v Razvityh Stranah [OPEC Sees the End of the Oil Age in Developed Countries]. 2020. Available online: https:/ / thebell.io/opek-uvidela-konets-epohi-nefti-v-razvityh-stranah (accessed on 30 November 2021).

45. WEC. COVID-19: Post-Crisis Futures. Short and Medium Term Scenarios. 2020. Available online: https://www.worldenergy. org/transition-toolkit/world-energy-scenarios / covid19-crisis-scenarios (accessed on 30 November 2021).

46. Song, S.; Li, T.; Liu, P.; Li, Z. The transition pathway of energy supply systems towards carbon neutrality based on a multi-regional energy infrastructure planning approach: A case study of China. Energy 2022, 238, 122037. [CrossRef]

47. Elshurafa, A.M.; Farag, H.M.; Hobbs, D.A. Blind spots in energy transition policy: Case studies from Germany and USA. Energy Rep. 2019, 520-528. [CrossRef]

48. Stokes, L.C.; Breetz, H.L. Politics in the U.S. energy transition: Case studies of solar, wind, biofuels and electric vehicles policy. Energy Policy 2018, 113, 76-86. [CrossRef]

49. Fragkos, P.; van Soest, H.L.; Schaeffer, R.; Reedman, L.; Köberle, A.C.; Macaluso, N.; Evangelopoulou, S.; De Vita, A.; Sha, F.; Qimin, C.; et al. Energy system transitions and low-carbon pathways in Australia, Brazil, Canada, China, EU-28, India, Indonesia, Japan, Republic of Korea, Russia and the United States. Energy 2021, 216, 119385. [CrossRef]

50. Liao, C.; Erbaugh, J.T.; Kelly, A.C.; Agrawal, A. Clean energy transitions and human well-being outcomes in Lower and Middle Income Countries: A systematic review. Renew. Sustain. Energy Rev. 2021, 145, 111063. [CrossRef]

51. Zhao, J.; Jiang, Q.; Dong, X.; Dong, K. Would environmental regulation improve the greenhouse gas benefits of natural gas use? A Chinese case study. Energy Econ. 2020, 87, 104712. [CrossRef]

52. Sofia, D.; Gioiella, F.; Lotrecchiano, N.; Giuliano, A. Cost-benefit analysis to support decarbonization scenario for 2030: A case study in Italy. Energy Policy 2020, 137, 111137. [CrossRef]

53. Oei, P.Y.; Brauers, H.; Herpich, P. Lessons from Germany's hard coal mining phase-out: Policies and transition from 1950 to 2018. Clim. Policy 2020, 20, 963-979. [CrossRef]

54. Baškarada, S. Qualitative case study guidelines. Qual. Rep. 2014, 19, 1-18. [CrossRef]

55. Simons, H. Case Study Research in Practice. University of Southampton, UK. 2009. Available online: https://books.google. ru/books?hl=ru\&lr=\&id=7WHMNYEe434C\&oi=fnd\&pg=PP2\&ots=N9IOfnnKRq\&sig=R_mAulxL6WpZTR3urZeQWJxQh8 $\mathrm{k} \&$ redir_esc $=\mathrm{y} \# \mathrm{v}=$ onepage \&q\&f$=$ false (accessed on 27 November 2021).

56. Shankar, A.V.; Quinn, A.K.; Dickinson, K.L.; Williams, K.N.; Masera, O.; Charron, D.; Jack, D.; Hyman, J.; Pillarisetti, A.; Bailis, R.; et al. Everybody stacks: Lessons from household energy case studies to inform design principles for clean energy transitions. Energy Policy 2020, 141, 111468. [CrossRef]

57. SES-Link. In-Depth Empirical Case Studies. Stockholm Resilience Centre, Stockholm University. Available online: https: //www.seslink.org/methods-2/in-depth-empirical-case-studies/ (accessed on 27 November 2021).

58. Bakhtin, P.; Saritas, O.; Chulok, A.; Kuzminov, I.; Timofeev, A. Trend monitoring for linking science and strategy. Scientometrics 2017, 111, 2059-2075. [CrossRef]

59. Calof, J.; Meer, D.; Vishnevskiy, K. Corporate foresight for strategic innovation management: The case of a Russian service company. Foresight 2020, 22, 14-36. [CrossRef]

60. Saritas, O.; Bakhtin, P.; Kuzminov, I.; Khabirova, E. Big data augmentated business trend identification: The case of mobile commerce. Scientometrics 2021, 126, 1553-1579. [CrossRef]

61. Aguilar, F.J. Scanning the Business Environment; McMillan: New York, NY, USA, 1967.

62. Akizu, O.; Urkidi, L.; Bueno, G.; Lago, R.; Barcena, I.; Mantxo, M.; Basurko, I.; Lopez-Guede, J.M. Tracing the emerging energy transitions in the Global North and the Global South. Int. J. Hydrog. Energy 2017, 42, 18045-18063. [CrossRef]

63. IEA. Key World Energy Statistics. August 2020. Available online: https:/ / www.iea.org/reports/key-world-energy-statistics-2020 (accessed on 2 December 2021).

64. Pravitel'stvo Rossijskoj Federacii [The Russian Government]. Rasporyazhenie ot 9 Iyunya 2020 g. № 1523-r Ob Utverzhdenii Energeticheskoj Sstrategii Rossijskoj Federacii na Pperiod do 2035 Ggoda [Energy Strategy of the Russian Federation until 2035 (Government Decree No. 1523-r of 2020)]. 2020. Available online: http:/ / static.government.ru/media/files/w4sigFOiDjGVDYT4 IgsApssm6mZRb7wx.pdf (accessed on 2 December 2021).

65. Kulapin, A. Rossijskoe Energeticheskoe Agentstvo Minenergo Rossii: Poluvekovoj Opyt v Novyh Realiyah [Russian Energy Agency of the Ministry of Energy of the Russian Federation: Half a Century of Experience in New Realities]. Energy Policy. 2020. Available online: https:/ / energypolicy.ru/a-kulapin-rossijskoe-energeticheskoe-agentstvo-minenergo-rossii-poluvekovojopyt-v-novyh-realiyah/business/2020/15/17/ (accessed on 20 November 2021).

66. Congress.gov. European Energy Security and Diversification Act of 2019. 2019. Available online: https://www.congress.gov/bill/116thcongress /house-bill /1453/text?q=\%7B $\% 22$ search $\% 22 \% 3 \mathrm{~A} \% 5 \mathrm{~B} \% 22 \mathrm{H} .+\mathrm{R} .+83 \% 22 \% 5 \mathrm{D} \% 7 \mathrm{D}$ (accessed on 20 November 2021).

67. Made in China 2025. Available online: http:/ / english.www.gov.cn/2016special/madeinchina2025/ (accessed on 20 November 2021).

68. Statista. Share of the Global Lithium-Ion Battery Manufacturing Capacity in 2020 with a Forecast for 2025, by Country (in Gigawatt Hours). 2021. Available online: https:/ /www.statista.com/statistics/1249871/share-of-the-global-lithium-ion-batterymanufacturing-capacity-by-country/ (accessed on 21 November 2021). 
69. World Population Review. Wind Power by Country. 2021. Available online: https://worldpopulationreview.com/countryrankings/wind-power-by-country (accessed on 21 November 2021).

70. Varro, L.; Fengquan, A. China's Net-Zero Ambitions: The Next Five-Year Plan Will Be Critical for an Accelerated Energy Transition. IEA. 2020. Available online: https:/ / www.iea.org/commentaries/china-s-net-zero-ambitions-the-next-five-yearplan-will-be-critical-for-an-accelerated-energy-transition (accessed on 20 November 2021).

71. Ladislaw, S.; Tsafos, N. Energy Spheres of Influence. CSIS. 2019. Available online: https://www.csis.org/analysis/energyspheres-influence (accessed on 20 November 2021).

72. Birol, F. India's Rise on the Global Energy Scene. IEA. 2020. Available online: https://www.iea.org/commentaries/indias-riseon-the-global-energy-scene (accessed on 20 November 2021).

73. DW. OPEC at 60: An Oil Cartel on Life Support. 2020. Available online: https://www.dw.com/en/opec-saudi-arabia-russiaunited-states-peak-oil-covid-19/a-54875289 (accessed on 15 November 2021).

74. Kaveshnikov, N. Evrosoyuz kak Game Changer Pravil Energeticheskoj Igry [EU as a Game-Changer of the Rules of the Energy Game]. Expert. 2017. Available online: https:/ / expert.ru/2017/12/18/evrosoyuz-kak-game-changer-pravil-energeticheskojigryi/ (accessed on 2 November 2021).

75. Statista. Leading Countries in Primary Energy Consumption Worldwide in 2019 (in Exajoules). 2020. Available online: https: //www.statista.com/statistics/263455/primary-energy-consumption-of-selected-countries/ (accessed on 27 September 2021).

76. IEA. Statistics Report World Energy Balances 2020 Overview; IEA: Paris, France, 2020.

77. World Nuclear Association. Nuclear Power in the USA. 2020. Available online: https://www.world-nuclear.org/ information-library / country-profiles / countries-t-z/usa-nuclear-power.aspx\#: \{\}:text=The\%20USA\%20is\%20the\%20world $\backslash$ T1 \textquoterights,20\%25\%20of\%20total\%20electrical\%20output (accessed on 23 September 2021).

78. Interfax. IMEMO i “Interfaks" Proveli Ttret'yu Ssessiyu Pproekta "Rossiya i Mmir: Pprofessional'nyj Rrazgovor"—Nna Eetot Rraz na Ttemu Eenergoperekhoda [IMEMO and Interfax Held the Third Session of the Project "Russia and the World: Expert Discussion"-This Time on the Topic the Energy Transition]. 2020. Available online: https://www.interfax.ru/presscenter/742321 (accessed on 23 September 2021).

79. President of Russia. Executive Order on the Russian Federation Economic Security Strategy until 2030. 2017. Available online: http:/ / docs.cntd.ru/document/ 420398070 (accessed on 23 September 2021).

80. Ministry of National Resources and Environment of the Russian Federation. Strategy for the Development of the Mineral Resource Base Until 2035. 2019. Available online: http:/ / www.mnr.gov.ru/docs/strategiya_razvitiya_mineralno_syrevoy_bazy_ rossiyskoy_federatsii_do_2035_goda/strategiya_razvitiya_mineralno_syrevoy_bazy_rossiyskoy_federatsii_do_2035_goda/ (accessed on 23 September 2021).

81. President of Russia. Strategy for Developing the Russian Arctic Zone and Ensuring National Security through 2035.2020. Available online: http:/ / static.kremlin.ru/media/events / files/ru/J8FhckYOPAQQfxN6Xlt6ti6XzpTVAvQy.pdf (accessed on 23 September 2021).

82. The Russian Government. 2050 Strategy of Social and Economic Development with Low Greenhouse Gas Emission. 2021. Available online: http:/ / static.government.ru/media/files / ADKkCzp3fWO32e2yA0BhtIpyzWfHaiUa.pdf (accessed on 8 December 2021).

83. Likhachev, V. Gibkij, no Nesgibaemyj Kitaj [Flexible, but Unyielding China]. RIAC. 2019. Available online: https:/ / russiancouncil. $\mathrm{ru} /$ analytics-and-comments/analytics/gibkiy-no-nesgibaemyy-kitay/ (accessed on 23 September 2021).

84. China Briefing. What to Expect in China's 14th Five Year Plan? Decoding the Fifth Plenum Communique. 2020. Available online: https:/ / www.china-briefing.com/news/what-to-expect-in-chinas-14th-five-year-plan-decoding-the-fifth-plenumcommunique/ (accessed on 23 September 2021).

85. The National Development and Reform Commission of the People's Republic of China. Energy Supply and ConsumptionRevolution Strategy 2016-2030. 2016. Available online: https://policy.asiapacificenergy.org/sites/default/files/Energy\%20Supply\%20 and $\% 20$ Consumption\%20Revolution\%20Strategy\%20\%282016-2030\%29\%20\%28CH\%29.pdf (accessed on 23 September 2021).

86. National Development and Reform Commission and the National Energy Administration. Guidance on the Promotion of Energy Storage Technology and Industry Development No.1701. 2017. Available online: http:/ /www.spartonres.ca/wp-content/ uploads /2017/10/Guidance-on-the-Promotion-of-Energy-Storage-Technology-and-Industry-Development.pdf (accessed on 23 September 2021).

87. Yixiu, W.; Zhe, Y. Climate and Energy in China's 14th Five Year Plan-The Signals So Far. China Dialogue. 2020. Available online: https: / chinadialogue.net/en/energy/chinas-14th-five-year-plan-climate-and-energy/ (accessed on 24 September 2021).

88. The White House. National Security Strategy of the United States of America. 2017. Available online: https://www.whitehouse. gov/wp-content/uploads/2017/12/NSS-Final-12-18-2017-0905.pdf (accessed on 30 August 2021).

89. Energy.gov. Energy Storage Grand Challenge Roadmap. 2020. Available online: https://www.energy.gov/sites/prod/files/2020 /12/f81/Energy\%20Storage\%20Grand\%20Challenge\%20Roadmap.pdf (accessed on 30 August 2021).

90. US Department of Energy. Restoring America's Competitive Nuclear Energy Advantage. A Strategy to Assure US National Security. 2020. Available online: https://www.energy.gov/sites/prod/files/2020/04/f74/Restoring\%20America\%27s\%20 Competitive\%20Nuclear\%20Advantage_1.pdf (accessed on 30 August 2021).

91. Raimondi, P.P. US Energy Policy under the Biden Administration: Domestic and Global Dimensions. Aspenia. International Analysis and Commentary. 2021. Available online: https://aspeniaonline.it/us-energy-policy-under-the-biden-administrationdomestic-and-global-dimensions / (accessed on 30 November 2021). 
92. Al Jazeera. To Tame Deficit, Saudi Arabia Plans 7\% Spending Cuts in 2021. 2020. Available online: https://www.aljazeera.com/ economy /2020/12/15/to-tame-deficit-saudi-arabias-plans-7-spending-cut-in-2021 (accessed on 6 December 2021).

93. Vision 2030. Investing for the Future. 2016. Available online: https://www.vision2030.gov.sa/en/node/384 (accessed on 30 November 2021).

94. ICLG.com. Saudi Arabia: Renewable Energy Laws and Regulations 2022. 2021. Available online: https://iclg.com/practiceareas/renewable-energy-laws-and-regulations/saudi-arabia (accessed on 30 November 2021).

95. Aramco. The Circular Carbon Economy. 2020. Available online: https://www.aramco.com/en/making-a-difference/planet/thecircular-carbon-economy (accessed on 30 November 2021).

96. S\&P Global. Energy Transition Aside, Saudi Arabia to Maintain Oil Exports 'for Decades,' Official Says. 2020. Available online: https:/ / www.spglobal.com/platts/ru/market-insights/latest-news/petrochemicals/112120-energy-transition-asidesaudi-arabia-to-maintain-oil-exports-for-decades-official-says (accessed on 13 November 2021).

97. Forbes. Radikal'no Novaya Neftyanaya Strategiya Saudovskoj Aravii [Saudi Arabia's Radically New Oil Strategy]. 2020. Available online: https://forbes.kz//life/opinion/radikalno_novaya_neftyanaya_strategiya_saudovskoy_aravii/ (accessed on 13 November 2021).

98. OGV. Energy Saudi Arabia Eyes Total Dominance In Oil and Gas. 2020. Available online: https://www.ogv.energy/news-item/ saudi-arabia-eyes-total-dominance-in-oil-and-gas (accessed on 13 November 2021).

99. Ministry of Petroleum Natural Gas. Shri Dharmendra Pradhan Invites India Inc. to Join the Atmanirbhar Bharat Urja Initiativessays That a Clear Roadmap of Aatma Nirbhar Urja for Aatma Nirbhar Bharat is Being Developed. 2020. Available online: https:/ / pib.gov.in/PressReleasePage.aspx?PRID=1681413 (accessed on 17 November 2021).

100. Government of India. PM Delivers Inaugural Address at 4th India Energy Forum. 2020. Available online: https:/ / pib.gov.in/ PressReleseDetailm.aspx?PRID=1667654 (accessed on 17 November 2021).

101. Make in India. Available online: https:/ / www.makeinindia.com/home (accessed on 17 November 2021).

102. Government of India. National Electricity Plan/Ministry of Power Central Electricity Authority. 2018. Available online: http:/ / www.cea.nic.in/reports/committee/nep/nep_jan_2018.pdf (accessed on 17 November 2021).

103. Mercom India. Solar Energy to Equal Coal's Share in India's Power Mix by 2040: IEA. 2021. Available online: https:// mercomindia.com/solar-equal-coals-share-india/ (accessed on 17 November 2021).

104. Ministry of Petroleum Natural Gas. About Biofuel. Available online: https://mopng.gov.in/en/refining/about-bio-fuel (accessed on 25 November 2021).

105. International Institute for Sustainable Development (IISD), Council on Energy, Environment and Water (CEEW). Mapping India's Energy Subsidies 2021: Time for Renewed Support to Clean Energy. Report 2021. Available online: https://www.iisd.org/ system/files/2021-07/mapping-india-energy-subsidies-2021.pdf (accessed on 25 November 2021).

106. Ministry of Petroleum Natural Gas. Shri Dharmendra Pradhan Dedicates to the Nation 201 CNG Plants and Commencement of PNG Supply in Jhansi; Inaugurates CNG Distribution through MRUs; Mobile Energy Fuelling is the Future in India, Says Shri Pradhan 2021. Available online: https:/ / pib.gov.in/PressReleasePage.aspx?PRID=1725330 (accessed on 17 November 2021).

107. Reuters India. LNG's Share of Indian Gas Demand to Rise to 70\% by 2030- Petronet CEO. 2021. Available online: https://www.reuters.com/world/india/lngs-share-indian-gas-demand-rise-70-by-2030-petronet-ceo-2021-06-17/ (accessed on 17 November 2021).

108. Petroleum and Natural Gas Regulatory Board of India. Natural Gas Pipelines Network in India- as on 30.09.2020. 2020. Available online: https:/ / www.pngrb.gov.in/databank/NGPLReports30092020.pdf (accessed on 17 November 2021).

109. Ambrosetti, E.T. The Climate Dimension of European Foreign Policy and EU's Neighbours. Valdai Discussion Club. 2020. Available online: https:/ /ru.valdaiclub.com/a/highlights/klimaticheskoe-izmerenie-vneshney-politiki/ (accessed on 14 September 2021).

110. EUR-Lex. The Energy Roadmap. Document 52011DC0885. 2011. Available online: https://eur-lex.europa.eu/legal-content/ EN/ALL/;ELX_SESSIONID=pXNYJKSFbLwdq5JBWQ9CvYWyJxD9RF4mnS3ctywT2xXmFYhlnlW1!-868768807?uri=CELEX: 52011DC0885 (accessed on 14 September 2021).

111. European Parliament. European Parliament Resolution of 14 March 2019 on Climate Change-A European Strategic LongTerm Vision for a Prosperous, Modern, Competitive and Climate Neutral Economy in Accordance with the Paris Agreement (2019/2582(RSP). 2019. Available online: https://www.europarl.europa.eu/doceo/document/TA-8-2019-0217_EN.html (accessed on 14 September 2021).

112. European Parliament. European Parliament Resolution of 15 January 2020 on the European Green Deal (2019/2956(RSP)). 2020. Available online: https:/ / www.europarl.europa.eu/doceo/document/TA-9-2020-0005_EN.html (accessed on 14 September 2021).

113. European Commission. Delivering the European Green Deal. 2019. Available online: https://ec.europa.eu/info/strategy/ priorities-2019-2024/european-green-deal/delivering-european-green-deal_en (accessed on 14 September 2021).

114. European Commission. National Long-Term Strategies. Available online: https:/ / ec.europa.eu/info/energy-climate-changeenvironment/implementation-eu-countries/energy-and-climate-governance-and-reporting/national-long-term-strategies_en (accessed on 14 September 2021).

115. European Commission. EU Energy in Figures: Main EU Energy Data in Your Pocket. 2021. Available online: https://ec.europa eu/info/news/eu-energy-figures-main-eu-energy-data-your-pocket-2021-sep-28_en (accessed on 14 September 2021).

116. BP. Statistical Review of World Energy 2021,70th ed. 2021. Available online: https:/ / www.bp.com/content/dam/bp/business-sites/en/ global/corporate/pdfs/energy-economics/statistical-review/bp-stats-review-2021-full-report.pdf (accessed on 19 November 2021). 